
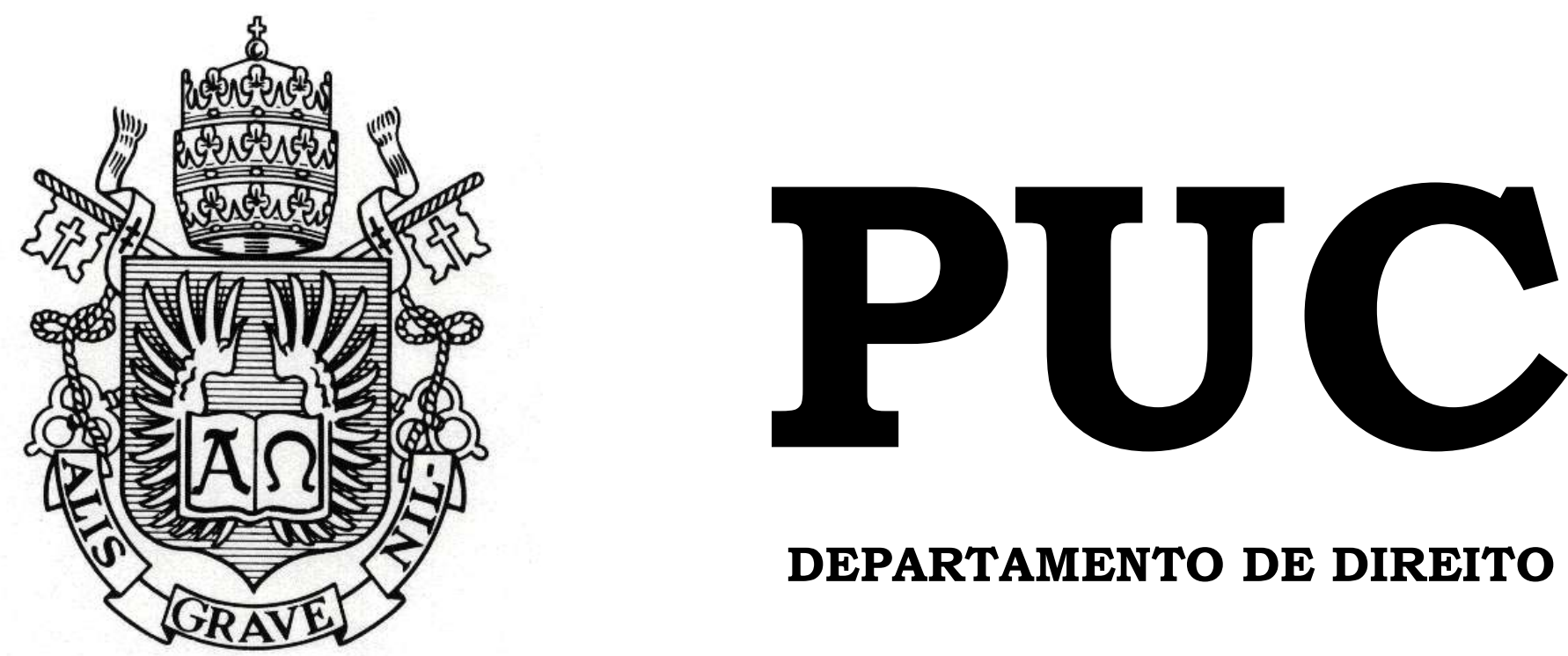

DEPARTAMENTO DE DIREITO

\title{
O PODER CONSTITUINTE
}

Uma visão crítica segundo as teses de Jacques Rancière e Antonio Negri

por

LUISA PRESSBURGER PORTUGAL

ORIENTADOR: Francisco de Guimaraens

2012.2

PONTIFÍCIA UNIVERSIDADE CATÓLICA DO RIO DE JANEIRO

RUA MARQUÊS DE SÃO VICENTE, 225 - CEP 22453-900

RIO DE JANEIRO - BRASIL 


\title{
O PODER CONSTITUINTE \\ Uma visão critica segundo as teses de Jacques Rancière e Antonio Negri
}

\author{
por \\ LUISA PRESSBURGER PORTUGAL
}

Monografia apresentada ao Departamento de Direito da Pontificia Universidade Católica do Rio de Janeiro (PUC-Rio) para a obtenção do Título de Bacharel em Direito.

Orientador: Francisco de Guimaraens 


\section{AGRADECIMENTOS}

A meu orientador e tutor no PET-Jur, Francisco de Guimaraens, por toda a ajuda e contribuição, não apenas para esse trabalho, mas durante a maior parte da minha formação universitária.

A todos os amigos da Contra Corrente, que tornaram a minha experiência nessa Universidade cada dia mais estimulante e que, em mais de um momento, me fizeram ver, na prática, a força da multidão.

A meus amigos do PET-Jur, não apenas por fazerem de todas as reuniões um prazer, mas também por me fazerem inúmeras vezes reavaliar minhas opiniões e por terem acrescentado tanto em minha formação.

A meu avô, por ser minha inspiração e meu herói.

A minha família e meus amigos, por terem me apoiado em todos os momentos, por terem estado sempre disponíveis para me guiar, me acalmar e me alegrar. 


\section{RESUMO}

O objetivo desse trabalho foi o de desafiar a tese tradicionalmente aceita acerca do conceito de poder constituinte. Em um primeiro momento, foi apresentada a definição desse conceito, tal como é hoje amplamente aceita pela doutrina, usando como base o pensamento de Sieyès, exposto em seu panfleto “Que é o Terceiro Estado?”; em seguida, foi realizada uma oposição entre os pensamentos de Espinosa e Hobbes, oposição esta que teve a finalidade de destacar conceitos espinosano fundamentais para embasar as teses de Rancière e Negri, apresentadas posteriormente. Através da obra de Rancière, "O Desentendimento", procurou-se ressaltar o fato de que a política é um momento de conflito e de produção, de ruptura com a ordem constituinte e que só pode ser compreendida através de uma visão democrática. Com Negri e sua obra "O Poder Constituinte", o objetivo foi o de estender a tese de Rancière, explicitando que o poder constituinte deve ser sempre pensado de forma aberta, dinâmica e ilimitada, seja através de uma perspectiva geográfica, temporal ou circunstancial.

\section{PALAVRAS-CHAVE}

Direito; política; poder; constituição; constitucionalismo; poder constituinte; Jacques Rancière; desentendimento; Antonio Negri; modernidade 


\section{SUMÁRIO}

1. Introdução 5

2. A Tese Tradicional

2.1. Uma breve análise da doutrina 9

2.2. "Que é o Terceiro Estado?" 12

2.3. Espinosa e Hobbes 18

3. Rancière e o Desentendimento

3.1. Conceitos básicos 28

3.2. O princípio da igualdade 31

3.3. A filosofia política 39

4. Negri e a Crise da Modernidade

4.1. Conceitos básicos 45

4.2. O conceito de uma crise 50

4.3. O antipoder 58

5. Conclusão 65

6. Bibliografia $\quad 69$ 


\section{INTRODUÇÃO}

Esse trabalho terá o objetivo de questionar o significado que o conceito "poder constituinte" assumiu para a tradição jurídicoconstitucionalista e as problemáticas que surgem com essa definição.

Como será desenvolvido mais adiante, pode-se dizer que para a ciência jurídica o poder constituinte realiza um movimento específico: ele aparece inicialmente como força motriz que leva à formação de uma nova sociedade; em seguida, é ele o responsável pela elaboração da Constituição que irá guardar as normas políticas fundamentais daquela comunidade, a qual deverá permanecer imodificável durante a existência de dita comunidade. Realizado esse movimento, o poder constituinte é relegado a um estado de latência, passando o povo a ser governado pelo chamado poder constituído, que será o responsável por organizar a vida sócio-política dessa nova sociedade. O poder constituinte só volta a se manifestar novamente se houver uma ruptura com a Constituição vigente. Nesse ponto, cai o poder constituído e forma-se um novo poder, reiniciando-se, assim, esse movimento.

O que será aqui questionado são as implicações antidemocráticas dessa concepção. Mais especificamente, será problematizada a ideia de transcendência do poder constituinte. De se pensar um poder constituinte eximido de qualquer responsabilidade sobre o que ele próprio constituiu; um poder constituinte imobilizado pelo poder constituído.

É plausível conceber um povo preso a um momento, pertencente a um passado utópico, em que um acordo de vontades decidiu quais seriam as leis de fundamentais de sua organização? Pode-se identificar quem é o povo que se submete a essas leis, mas não é possível identificar quem foram aqueles que a constituíram. E qual seria a consequência de se pensar no povo que se submete a um poder constituído como um povo diferente daquele do poder constituinte em um sistema que pressupõe que o poder constituinte, assim que forma uma nova sociedade, desaparece? Nesse 
sentido, só seria possível supor que o poder constituinte, uma vez que se tornasse constituído, já estaria ultrapassado. E se não imediatamente, qual seria esse limite temporal? Quanto tempo deve afastar um povo de sua constituição para que ele deixe de ser o povo que a constituiu?

Também é preciso questionar quem seria o sujeito desse poder constituinte: ao que corresponderia a chamada "vontade comum", o acordo das vontades individuais do povo do poder constituinte. Aqui novamente é pressuposto que essa vontade comum permaneça constante. E observe-se: para que a vontade comum permaneça constante, é preciso que as vontades individuais também permaneçam as mesmas. Mas que vontades individuais são essas que formaram inicialmente a vontade comum? Como um individuo poderá averiguar se a sua vontade individual está ou não abarcada na dita "vontade comum"? E qual seria o significado se esse indivíduo resolvesse que não, sua vontade não faz parte da vontade comum? Estaria ele excluído dessa sociedade? Ou isso significaria que a Constituição como um todo não corresponde mais aos anseios daquele povo, ensejando, portanto, uma manifestação de um novo poder constituinte, com uma nova vontade comum?

E, por fim, o que seria a política no meio disso? O cenário está imobilizado: todas as normas fundamentais estão dadas e não podem ser alteradas. Será possível pensar em política dentro do poder constituído? Ou a política só irá aparecer nesse breve e abstrato momento de manifestação do poder constituinte? Mas ainda assim: é possível se pensar em uma política que preexista à fundação de uma sociedade? Seria ela, então, apenas responsável pelo acordo de vontades e pela delegação de poder a um soberano? As implicações dessa linha de pensamento parecem levar a crer que não seria possível conceber nenhuma forma de manifestação ou reinvindicação dentro do poder constituído.

Como fio condutor para que sejam pensadas essas perguntas, esse trabalho irá se centralizar em torno de duas obras que apresentam um pensamento crítico sobre o tema do poder constituinte. 
Primeiramente, será feita uma análise do livro "O Desentendimento - Política e Filosofia”, de Jacques Rancière. Essa obra de 1996 apresenta uma concepção de política que desafia o senso comum: o desentendimento de seu título é o conceito chave para entende-la. Para o autor, de forma resumida, a política é uma disputa que tem como base o questionamento de uma parcela da sociedade sobre os privilégios da outra. As instituições que tem como objetivo a conservação do estado das coisas estão excluídas dessa definição, elas pertencem à polícia. A política será sempre uma ruptura, uma disputa.

Rancière apresenta esse conflito como um conflito entre duas partes: de um lado está a parcela dos com parcela, dos privilegiados; do outro, a parcela dos sem parcela. A disputa apenas acontece quando essa parcela dos sem parcela se identificar como tal e, feita essa subjetivação, entra em confronto com esses privilegiados: o objetivo final dessa disputa é o que o autor irá chamar de uma nova partilha do sensível. Essa tese será mais adequadamente desenvolvida no capítulo dedicado ao autor, mas por ora as palavras do próprio servirão para que se vislumbre como suas ideias desafiam a tradição jurídico política:

\begin{abstract}
"As páginas que se seguem tentarão portanto definir alguns referenciais para um entendimento do desentendimento segundo o qual a aporia da política é acolhida a título de objeto filosófico. Nela tentaremos proar a seguinte hipótese: o que se chama de 'filosofia política' poderia muito bem ser o conjunto das operações de pensamento pelas quais a filosofia tenta acabar com a política, suprimir um escândalo de pensamento adequado ao exercício da política. Esse escândalo teórico, por sua vez, é apenas a racionalidade do desentendimento. O que torna a política um objeto escandaloso é que a política é a atividade que tem por racionalidade própria a racionalidade do desentendimento."
\end{abstract}

A segunda obra analisada será "O Poder Constituinte - ensaio sobre as alternativas da modernidade", escrita por Antonio Negri em 1992. O ponto central desse livro é um questionamento sobre como pensar um poder constituinte verdadeiramente ilimitado. Para tanto, ele percorre os eventos

\footnotetext{
${ }^{1}$ RANCIÈRE, Jacques. O Desentendimento - política e filosofia; tradução de Ângela Leite Lopes - São Paulo: Ed. 1. Editora 34, 1996, p. 14
} 
históricos que ajudaram a moldar o pensamento de poder constituinte tal como nos é apresentado e ataca a racionalidade moderna como forma de construir uma nova racionalidade que possa se adequar ao conceito de poder constituinte tal como ele propõe: uma relação entre potência e multidão.

Para Negri, o constitucionalismo é o grande inimigo do poder constituinte. Ao limitá-lo a uma forma determinada, ele irá neutralizá-lo, expropria-lo de sua potência produtiva. Na tradição constitucionalista, o poder constituinte é limitado pelo poder constituído. Para que isso não ocorra, o autor tenta apresentar uma noção de poder constituinte que se baseia na produção do trabalho vivo: um poder constituinte que esteja ligado não apenas ao político mas também ao social. Assim, sem nos estendermos aqui na definição de sua obra, cabe destacar um trecho em que o autor deixa claro como a sua tese desafia a tradição constitucionalista:

\begin{abstract}
"O que é, na perspectiva da ciência jurídica, o poder constituinte? É a fonte de produção das normas constitucionais, ou seja, o poder de fazer uma constituição e assim ditar as normas fundamentais que organizam os poderes do Estado. Em outros termos, é o poder de instaurar um novo ordenamento jurídico e, com isto, regular as relações jurídicas no seio de uma nova comunidade. ' $O$ poder constituinte é um ato imperativo da nação que surge do nada e organiza a hierarquia dos poderes'. Eis-nos, com esta definição, diante de um paradoxo extremo: um poder que surge do nada e organiza todo o direito... Um paradoxo que, precisamente pelo seu caráter extremo, é insustentável."2
\end{abstract}

Desse modo, essas serão os dois marcos aqui utilizados. Em alguns momentos essas teorias irão coincidir, em outras se distanciar. Ainda haverá momentos em que elas serão complementares ou contraditórias. Mas, de forma geral, elas servirão como base para que se possa extrair um conceito de poder constituinte que realmente permita a construção de uma sociedade livre, igualitária e absolutamente democrática.

\footnotetext{
${ }^{2}$ NEGRI, Antonio. O Poder Constituinte - ensaio sobre as alternativas da modernidade; tradução de Adriano Pilatti - Rio de Janeiro: Ed. 1, DP\&A, 2002. pp. 8, 9
} 


\title{
2. A TESE TRADICIONAL
}

\subsection{Uma Breve Análise da Doutrina}

No livro "Curso de Direito Constitucional Brasileiro", Paulo Gustavo

Gonet Branco define o conceito de poder constituinte da seguinte forma:

\begin{abstract}
"A autoridade máxima da Constituição, reconhecida pelo constitucionalismo, vem de uma força política capaz de estabelecer e manter o vigor normativo do Texto. Essa magnitude que fundamenta a validez da Constituição, desde a Revolução Francesa, é conhecida com o nome de poder constituinte originário.

"Ao contrário do que ocorre com as normas infraconstitucionais a Constituição não retira o seu fundamento de validade de um diploma jurídico que lhe seja superior, mas se firma pela vontade das forças determinantes da sociedade, que a precede.

"Poder constituinte originário, portanto, é a força política consciente de si que resolve disciplinar os fundamentos do modo de convivência na comunidade política."
\end{abstract}

A partir desse trecho, podemos ver que segundo a tese tradicionalmente aceita, o poder constituinte é uma força política que fundamenta a validez da Constituição. Além disso, nos é informado que essa força corresponde a vontade das forças determinantes da sociedade. Por fim, cabe destacar que o poder constituinte precede essa sociedade, antecedendo a comunidade política que ele disciplina. Nesse sentido também a lição de Jorge Miranda:

"O poder constituinte é logicamente anterior e superior aos poderes ditos constituídos - na tricotomia clássica, o legislativo, o executivo e o judicial. A Constituição, sua obra, define-os e enquadra-os quer formal quer materialmente: eles não podem ser exercidos senão no âmbito da Constituição e as decisões e as normas que resultem desse exercício não podem contrariar o sentido normativo da Constituição."

Em outras palavras, podemos pensar em poder constituinte como uma força que transcende aquela sociedade. Que surge através da

${ }^{3}$ MENDES, Gilmar Ferreira, COELHO, Inocêncio Martires, BRANCO, Paulo Gustavo Gonet. Curso de Direito Constitucional. 4. ed. rev. e atual. São Paulo. Saraiva. 2009. p. 231

${ }^{4}$ MIRANDA, Jorge. Teoria do Estado e da Constituição. Rio de Janeiro: Forense, 2003. p. 375 
associação de determinadas vontades, constitui uma nova sociedade política, determinando as regras que esta deverá seguir e, depois de instituída essa nova comunidade política, desaparece da mesma forma que surgiu, deixando como vestígio de sua existência apenas um conjunto de normas que deverá ser seguido para que se perpetue a existência dessa sociedade.

Para explicitar o que significa esse conceito, podemos usar como exemplo a diferenciação, tão comum na doutrina e jurisprudência, entre "poder constituinte originário" e "poder constituído", também chamado de "poder constituinte derivado" ou "reformador". Sobre o tema, enuncia José Afonso da Silva:

\begin{abstract}
"A Constituição, como se vê, conferiu ao Congresso Nacional a competência para elaborar emendas a ela. Deu-se, assim, a um órgão constituído o poder de emendar a Constituição. Por isso se lhe dá a denominação de poder constituinte instituído ou poder constituído. Por outro lado, como seu poder não lhe pertence por natureza, primariamente, mas ao contrário, deriva de outro (isto é, do poder constituinte originário), é que também se lhe reserva o nome de poder constituinte derivado, embora parece mais acertado falar em competência constituinte derivada ou constituinte de segundo grau. Trata-se de um problema de técnica constitucional, já que seria muito complicado ter que convocar o constituinte originário todas as vezes em que fosse necessário emendar a Constituição."
\end{abstract}

O que se pretende demonstrar com esse trecho é a cisão que a atual teoria estabelece entre o poder constituinte (originário) e a sociedade que ele instituiu. Apenas nesse sentido pode-se conceber a necessidade de "invocar" esse poder, quase como se ele fosse um espírito adormecido. E ainda mais: se o dito poder constituído atua em matérias que inicialmente caberiam ao poder constituinte, o que diferencia um do outro? Será que não é possível pensar em um poder constituinte que possa ser atuante em um momento posterior à instauração da ordem político jurídica?

\footnotetext{
${ }^{5}$ DA SILVA, José Afonso. Curso de Direito Constitucional Positivo. 32. ed. rev. e atual. São Paulo. Malheiros Editores. 2009. pp. 64, 65
} 
Segundo essa linha de pensamento, a própria noção comumente aceita de um poder constituinte ilimitado se torna contraditória. Observe-se os trechos a seguir destacados:

\begin{abstract}
"O Poder Constituinte originário estabelece a Constituição de um novo Estado, organizando-o e criando os poderes destinados a reger os interesses de uma comunidade. Tanto haverá Poder Constituinte no surgimento de uma primeira Constituição, quanto na elaboração de qualquer Constituição posterior.

"A ideia da existência de um Poder Constituinte é o suporte lógico de uma Constituição superior ao restante do ordenamento jurídico e que, em regra, não poderá ser modificado pelos poderes constituídos. É pois, esse Poder Constituinte, distinto, anterior e fonte de autoridade dos poderes constituídos, com eles não se confundindo."
\end{abstract}

E, em seguida: "O Poder Constituinte é ilimitado e autônomo, pois não está de modo algum limitado pelo direito anterior não tendo que respeitar os limites postos pelo direito positivo antecessor." "7 A contradição estaria, então, no fato de se afirmar que o poder constituinte é ilimitado pois não está vinculado à ordem anterior, ignorando o fato que segundo as definições aqui apresentadas, o poder constituinte é limitado pela própria ordem que ele constitui, já que, como foi dito acima, esta difere radicalmente da potência que a constituiu.

Ainda pode-se notar que o mesmo autor afirma que:

“(...) Poder Constituinte é permanente, pois não desaparece com a realização de sua obra, ou seja, com a elaboração de uma nova Constituição. Como afirmado por Sieyès, o Poder Constituinte não esgota sua titularidade, que permanente latente, manifestando-se novamente mediante uma nova Assembleia Nacional Constituinte ou um ato revolucionário" 8

A pergunta que resta, então, é: se o poder constituinte não desaparece durante os períodos de constitucionalização, onde está ele? O que significa um poder constituinte "latente", limitado ao poder constituído? Afirmar que ele irá se manifestar pontualmente nos momentos de revolução ou nas Assembleias Constituintes não corresponde ao pensamento de um poder

\footnotetext{
${ }^{6}$ MORAES, Alexandre de. Direito Constitucional - 20 ed. - São Paulo: Atlas, 2006. p. 22

${ }^{7}$ Ibid.. p. 23

${ }^{8}$ Ibid.. p. 23
} 
constituinte contínuo, mas sim um poder constituinte fragmentado. Os problemas no conceito não se resolvem se ao invés de pensarmos em um poder constituinte que desaparece após a Constituição, passarmos a pensar em um poder constituinte que meramente "hiberna".

Os questionamentos aqui apresentados serão retomados de forma mais aprofundada ao longo desse trabalho, mas antes é necessário que se solidifique a ideia de poder constituinte tal qual é comum e tradicionalmente aceita no meio jurídico. Para tanto, realizaremos uma breve análise do texto escrito por Emmanuel Joseph Sieyès às vésperas da Revolução Francesa, em janeiro de 1789, “A Constituinte Burguesa - Que é o Terceiro Estado?’. Esse documento tem enorme influência em toda teoria constitucional, servindo como marco para o desenvolvimento do conceito ora sob análise.

\section{2. "Que é o Terceiro Estado?"}

Em seu panfleto "Que é o Terceiro Estado?", Sieyès tinha como objetivo definir a posição política do Terceiro Estado dentro da sociedade francesa, demonstrando como o corrente sistema de votos dos Estados Gerais impedia qualquer forma de participação política dessa parcela da sociedade, ainda que esta correspondesse, quantitativamente, a sua maioria.

A questão estava no fato dos votos não serem computados por cabeça, mas por ordens. Dessa forma, o Primeiro e o Segundo Estados, compostos pelo clero e pela nobreza, ainda que somassem apenas cerca de duzentos mil privilegiados, tinham mais poder político que os vinte e cinco milhões de indivíduos que compunham o Terceiro Estado ${ }^{9}$. Para Sieyès era importante, antes de tudo, estabelecer a verdadeira importância do Terceiro Estado. Assim, ele enuncia:

\footnotetext{
9“'Desse modo, não há, no total, duzentos mil privilegiados das duas primeiras ordens. Comparem este número com o de vinte e cinco a vinte seis milhões de almas, e poderão julgar a questão." (SIEYÈS, Emmanuel Joseph. A constituinte burguesa: Qu'est-ce que letiersétat? - $4^{\mathrm{a}}$ ed. Organização e introdução de Aurélio Wander Bastos. Tradução. por Norma Azevedo. Rio de Janeiro: Lumen Juris, 2001. p. 72)
} 
"Quem ousaria assim dizer que o Terceiro Estado não tem em si tudo o que é preciso para formar uma nação completa? Ele é o homem forte e robusto que está ainda com um braço preso. Se se suprimisse as ordens privilegiadas, isso não diminuiria em nada a nação; pelo contrário, lhe acrescentaria. Assim, o que é o Terceiro Estado? Tudo, mas um tudo entravado e oprimido. O que seria ele sem as ordens de privilégios? Tudo, mas um tudo livre e florescente. Nada pode funcionar sem ele, as coisas iriam infinitamente melhor sem os outros."

Mas o que exatamente seria o Terceiro Estado? Segundo o autor, o Terceiro Estado é a nação e, consequentemente, tudo que está fora do Terceiro Estado não pertence à nação. E não pertencem a esse grupo todos aqueles que são, de alguma forma, privilegiados pela lei: o Terceiro Estado é o "conjunto dos cidadãos que pertencem à ordem do comum"11.

Assim, o que Sieyès propõe é que a França seja vista não como uma simples monarquia, mas como uma aristocracia "da Igreja, da Espada e da Toga", já que os privilegiados formam uma classe separada e oposta a dos homens comuns, detendo os primeiros todo o poder, dominando os Estados Gerais e, assim, influenciando não apenas o poder legislativo, mas também os poderes executivo e judicial.

\footnotetext{
"Parece que, às vezes, as pessoas se surpreendem ouvindo a queixa que existe uma tripla 'aristocracia': da Igreja, da Espada e da Toga. (...) Se os Estados Gerais são os intérpretes da vontade geral e, como tal, detêm o poder legislativo, não é verdade que, ali, onde os Estados Gerais não passam de uma assembleia clerical, nobiliárquica e judicial, haja uma verdadeira aristocracia?

“(..) Uma espécie de espírito de confraternidade faz com que os nobres se prefiram entre si ao resto da nação. A usurpação é total. Eles reinam de verdade.

“(...) é um grande erro acreditar que a França está submetida a um regime monárquico. Se suprimirmos de nossos anais alguns anos de Luís XI, de Richelieu, e alguns momentos de Luís XIV, em que se vê o despotismo puro e simples, vamos pensar estar lendo a história de uma aristocracia 'áulica'. Foi a corte que reinou, e não o monarca." 12
}

Porém, como já foi dito, na concepção do autor, o Terceiro Estado corresponde à própria nação e oprimir o Terceiro Estado é o mesmo que

\footnotetext{
${ }^{10} I b i d .$, p. 55

${ }^{11}$ Ibid., p. 58

${ }^{12}$ Ibid., pp. 60,61
} 
oprimir a nação como um todo, sendo, portanto, imprescindível garantir a participação política deste.

Para corroborar sua tese, ele adotaem seu trabalho uma concepção contratualista acerca da formação das comunidades políticas, afirmando que esse processo ocorre em três etapas: na primeira, ocorre a associação de indivíduos isolados, formando uma nação através da associação das vontades individuais; na segunda, a nação entra em acordo sobre seus bens e direitos e as vontades individuais são unidas em uma vontade comum; por fim, o poder é delegado para um grupo, que passa a ser o responsável pelo exercício da vontade nacional, que passa a ser não mais a vontade comum, mas a vontade comum representativa:

\begin{abstract}
"Distingo a terceira época da segunda, pois não é mais a vontade comum real que age, é uma vontade comum representativa. Dois caracteres indestrutíveis lhe pertencem, é preciso repetir: $1^{\circ}$ ) esta vontade do corpo dos representantes não é plena e ilimitada, é somente uma parte da grande vontade comum nacional; $2^{\circ}$ ) os delegados não a exercem como um direito próprio, é o direito do outro: a vontade comum é comissionada."13
\end{abstract}

Já aparece aqui a ruptura entre poder constituinte e poder delegado. A partir do momento em que a nação escolhe por constituir um governo, a vontade comum parece se retirar do corpo social. A partir desse ponto, essa força, correspondente à soma das vontades individuais, cessa de existir, a não ser por seus reflexos na Constituição daquela sociedade. Parece que nem o governo, nem o próprio povo que forma essa nação podem, de alguma forma, alcançar essa ideia, restando a eles se conformar com uma sombra dela, a dita vontade comum representativa, esvaziada esta de qualquer força constitutiva. Assim, só resta a eles seguir exatamente as normas que foram criadas no breve instante da manifestação do poder constituinte originário. É o que Negri descreve como um "paradoxo

\footnotetext{
${ }^{13}$ Ibid., p. 93
} 
extremo", em sua obra "O Poder Constituinte", "um poder que surge do nada e organiza todo o direito". 14

"Um corpo submetido a formas constitutivas só pode decidir segundo a Constituição. Não pode dar-se outra. Deixa de existir a partir do momento em que se move, que fala, atua de forma diferente das que lhe foram impostas. Os Estados Gerais, mesmo quando reunidos, são incompetentes para decidir sobre a Constituição. Este direito pertence unicamente à nação, independente, não cansamos de repetir, de qualquer forma e qualquer condição." 15

Assim, o que é importante de se observar nesse trecho é que, para o autor, um corpo político deixa de existir no momento em que ele passa a agir de forma contrária ao que está instituído em sua Constituição. Mas não cabe aos integrantes desse corpo modificar suas normas: apenas quem poderia intervir é a nação, essa vontade nacional, que segundo Sieyès “(...)existe antes de tudo, ela é a origem de tudo. Sua vontade é sempre legal, é a própria lei. Antes dela e acima dela só existe o direito natural."16. Fica explicitada, mais uma vez, a ideia de um poder constituinte transcendente. A nação, o sujeito do poder constituinte, se encontra fora do pacto social que ela própria criou:

"Devemos conceber as nações sobre a terra como indivíduos fora do pacto social, ou, como se diz, no estado de natureza. O exercício de sua vontade é livre e independe de todas as formas civis.

“(...) uma nação é independente de qualquer formalização positiva, basta que sua vontade apareça para que todo direito político cesse, como se estivesse diante da fonte e do mestre supremo de todo direito positivo."17

Ou seja: o poder constituinte apenas pode atuar de fora para dentro, agindo como uma força que apenas se manifesta para romper com a ordem constitucional vigente até que uma nova ordem seja instaurada e ele possa voltar ao seu estado de inércia anterior.

\footnotetext{
14“"Eis-nos, com esta definição, diante de um paradoxo extremo: um poder que surge do nada e organiza todo direito. Um paradoxo que, precisamente pelo seu caráter extremo, é insustentável. E, no entanto, a ciência jurídica nunca se exercitou tanto naquele jogo de afirmar e negar, de tomar algo como absoluto e depois estabelecer-lhe limites - que é tão próprio do seu trabalho lógico como o fez a propósito do poder constituinte."Ibid., p. 9

${ }^{15}$ Ibid., p. 100

${ }^{16}$ Ibid., p. 94

${ }^{17}$ Ibid., p. 96
} 
É por isso que Sieyès se refere à necessidade de representantes ordinários e extraordinários. Sendo impossível alcançar essa abstrata "nação", para que um corpo político possa funcionar após sua constitucionalização é preciso delegar esse poder para aqueles que exercerão, nas formas previstas constitucionalmente, a porção da vontade comum correspondente à administração da coisa pública, sendo estes os representantes ordinários. Os representantes extraordinários, por sua vez, seriam os integrantes de uma Assembleia Constituinte; eles teriam como objetivo representar a vontade nacional antes da constitucionalização, sendo estes "deputados somente para um único assunto, e por um determinado tempo."18

Importante ressaltar, assim, que esses representantes extraordinários deverão representar exatamente a composição de uma nação. Isso ocorre porque como já foi enunciado anteriormente, Sieyès defende que a vontade comum corresponde exatamente à soma das vontades individuais. Por isso, a única maneira de se aproximar da verdadeira vontade nacional seria que essas Assembleias mantivessem exatamente a mesma proporção de indivíduos que pertencem à classe dos privilegiados e à classe dos não privilegiados que a própria nação e, mais do que isso, que o voto fosse computado por cabeça, de forma a não alterar essa representatividade.

\footnotetext{
"Desse modo, se pretendermos que faça parte da Constituição francesa o fato de que duzentos ou trezentos mil indivíduos de um total de vinte milhões de cidadãos correspondam a dois terços da vontade comum, o que responder, senão que estamos afirmando que dois e dois são cinco?

"As vontades individuais são os únicos elementos da vontade comum. Não é possível privar o número maior do direito de expressá-la, nem tampouco decretar que dez vontades só valem uma contra outras dez que valerão por trinta. São contradições nos termos, verdadeiros absurdos." 19
}

Seguindo os fatores acima apresentados, Sieyès vai delimitar os anseios do Terceiro Estado em três petições: "Que os representantes do Terceiro Estado sejam escolhidos apenas entre os cidadãos que realmente

\footnotetext{
${ }^{18}$ Ibid., p. 98

${ }^{19}$ Ibid., p. 101
} 
pertençam ao Terceiro Estado"20; "Que seus deputados sejam em números iguais ao da nobreza e do clero"21; "Que os Estados Gerais votem não por ordens, mas por cabeças" 22 . Por outro lado, ele aponta que a casta dos privilegiados afirma que a França já possui uma Constituição, e que esta possui apenas duas disposições intocáveis: a divisão por ordem dos cidadãos e a igualdade de influência para cada ordem. Assim, diante desse impasse, o autor irá apresentar um questionamento:

\begin{abstract}
"Em toda nação livre - e toda nação deve ser livre - só há uma forma de acabar com as diferenças, que se produzem com respeito à Constituição. Não é aos notáveis que se deve recorrer, é à própria nação. Se precisamos de Constituição, devemos fazê-la. Só a nação tem direito de fazê-la. Se temos uma Constituição, como alguns se obstinam em afirmar, e que por ela a assembleia geral é dividida, de acordo com o que pretendem, em três câmaras de três ordens de cidadãos, não podemos, por isso deixar de ver que existe da parte de uma dessas ordens uma reclamação tão forte, que é impossível avançar sem julgá-la. E quem é que deve resolver tais divergências?"23
\end{abstract}

A sua resposta, por tudo que já foi aqui exposto, é bastante previsível. Para Sieyès, o Terceiro Estado tem força para representar sozinho o interesse nacional. Mais do que isso, é imprescindível que o faça para que se obtenha uma restauração dos interesses nacionais, afirmando que não se trata meramente de avançar ou permanecer como está: "Trata-se de avançar ou de recuar" 24 . O autor, assim, propõe que ao invés de se reunir nos Estados Gerais, o Terceiro Estado se reúna sozinho em uma Assembleia Nacional, na qual irá decidir por toda nação:

\footnotetext{
"Vocês se queixam que se o Terceiro Estado se reúne separadamente para formar, não os três estados ditos gerais, mas a assembleia nacional. Ora, ele será tão competente para votar pelo clero e a nobreza, quanto essas duas ordens o são para deliberar pelo povo. Inicialmente, peço-lhes que observem, como acabamos de dizer, que os representantes do Terceiro Estado terão, incontestavelmente, a procuração dos vinte e cinco ou vinte e seis milhões de indivíduos que compõem a nação, excetuando-se cerca de duzentos mil nobres ou padres. Isso já basta para
}

\footnotetext{
${ }^{20}$ Ibid., p. 65

${ }^{21}$ Ibid., p. 70

${ }^{22}$ Ibid., p. 74

${ }^{23}$ Ibid., p. 91

${ }^{24}$ Ibid., p. 107
} 
que tenham o título de Assembleia Nacional. Vão deliberar, pois, sem nenhuma dificuldade pela nação inteira, excetuando-se somente duzentas mil cabeças." ${ }^{25}$

Assim, Sieyès irá encerrar seu panfleto propondo que o Terceiro Estado, por meio de seus representantes, seja chamado para dispor sobre a vontade da nação. Ou seja: seus representantes deverão ser convocados, de forma extraordinária, para decidirem sobre a própria Constituição, sobre a forma política do Estado. A Assembleia Nacional será, portanto, um exercício do poder constituinte, mas, segundo a divisão previamente estabelecida por Sieyès, o que estará em ato aqui não será o poder constituinte originário, mas apenas a sua forma delegada:

\begin{abstract}
"A organização de uma representação extraordinária, ou, pelo menos, a concessão de um novo poder especial, tal como foi explicado acima, para regular, antes de tudo, o grande problema da constituição, é, pois, o verdadeiro meio de colocar um fim à dissensão e aos possíveis problemas da nação. Mesmo se não houvesse nada a se temer desses problemas, ainda assim seria uma medida a ser tomada, porque, tranquilos ou não, não podemos deixar de conhecer nossos direitos políticos e de tomar posse deles. Esta necessidade nos parece ainda mais urgente se pensamos que os direitos políticos são a única garantia dos direitos civis e da liberdade individual." 26
\end{abstract}

\title{
2.3. Espinosa e Hobbes
}

Encerrarei esse primeiro capítulo utilizando como guia a última parte do livro "Política em Espinosa", escrito por Marilena Chauí. O objetivo aqui será analisar a comparação entre as filosofias políticas de Hobbes e Espinosa, tal como proposto pela autora, com o fim de delimitar dois tópicos que serão essenciais para a continuidade desse trabalho: por que a multidão deve ser entendida como mais do que mera soma das vontades individuais epor que nós iremos nos referir a um poder constituinte imanente e não mais a um poder constituinte transcendente.

Assim, para recapitular o que foi apresentado acima: segundo a tese tradicionalmente aceita, inspirada em grande parte pelos contratualistas e

\footnotetext{
${ }^{25}$ Ibid., pp. 109,110

${ }^{26}$ Ibid., p. 113
} 
pelo trabalho de Sieyès, o movimento de formação política de uma sociedade se daria pela associação de indivíduos e pela construção de uma vontade comum que corresponderia à exata soma de todas as vontades individuais; posteriormente, o poder de decisão seria delegado a um indivíduo ou a um grupo de indivíduos, passando a se falar em um governo e em uma vontade comum representativa. A partir desse momento, o exercício da soberania só se daria por meio desse representante, que seria, portanto, o soberano. Com isso, o poder constituinte, que estava presente durante a associação dos indivíduos e a constituição da vontade comum, passa a apenas se apresentar no que é chamado de sua forma latente, sendo que dentro da sociedade política o que está em atividade é o poder delegado.

Dessa breve explicação, portanto, podemos destacar os dois pontos essenciais que serão aqui discutidos: o fato de que poder constituinte teria como sujeito a vontade comum, que nada mais é do que a soma das vontades individuais; e o de que poder constituinte seria transcendente em relação ao corpo político que ele constrói, ou seja, não o integra e apenas irá atuar de fora para dentro, podendo-se dizer que ele desaparece após a transição do Estado de Natureza para a sociedade civil

Com esses pontos claros, podemos começar apontado as semelhanças entre os dois filósofos. Assim, o que pode ser destacado é que, tanto para Espinosa como para Hobbes, o Estado de Natureza é apresentado como um momento em que as paixões dos indivíduos definem suas relações interpessoais. Sendo assim, esse estado pode ser visto como uma guerra passional e são os conflitos que surgem a partir daí que resultarão na criação de uma política. É importante notar também que os dois autores se esforçam por retirar a política do campo da superstição e transformá-la em uma ciência. Por fim, a concepção de direito natural deles, apesar de possuir uma diferença fundamental que será abordada a seguir, também tem algumas semelhanças: em ambos os casos, o direito natural é entendido como um poder (de auto conservação) e como um fato, afastando assim 
dele uma noção de subjetividade presente em alguns jusnaturalistas, como se esse direito dependesse de um exercício de uma racionalidade. Além disso, esses filósofos não concordam com o termo "lei natural" porque eles negam a existência de uma autoridade no Estado de Natureza capaz de propor tais leis.

Chegamos, assim, na grande ruptura entre as teses de Espinosa e Hobbes, diferença esta que irá servir como fio condutor pelo resto desse trabalho: enquanto para Hobbes (e os demais filósofos contratualistas), o direito natural não subsiste dentro de uma sociedade civil constituída, para Espinosa não só ele existe, como pode-se dizer que sua existência depende da constituição dessa sociedade ${ }^{27}$.

\begin{abstract}
“A resposta de Espinosa é curiosa. Parece sugerir que concorda com Hobbes no restante as ideias politicas, restringindo a diferença apenas à relação entre direito natural e direito civil. Ora, visto que a articulação desses dois direitos determina a gênese da própria vida política, podemos supor que as consequências dessa única divergência sejam de grande envergadura. Não será ela, por exemplo, que leva Hobbes a considerar a monarquia como o instrumento mais adequado para a realização do Leviatã, enquanto Espinosa diz ser a democracia 'o mais natural dos regimes políticos'?"28
\end{abstract}

Para chegar ao cerne da questão, deve-se começar apontando qual o fundamento da política para cada um dos autores. Como já foi mencionado, no Estado de Natureza os homens estão submetidos as suas paixões e, por isso, se manifestam por meio de uma violência natural que transforma o convívio em uma guerra passional. Porém, enquanto para Hobbes esta paixão está no fato de que todos os homens querem o poder, para Espinosa a paixão significa o desejo de todos os homens de governar e não serem governados. Parece uma distinção sútil, mas o que irá resultar disso é que

\footnotetext{
${ }^{27} \mathrm{Na}$ Carta $\mathrm{n}^{\mathrm{o}}$ 50, de 2 de junho de 1674, Espinosa afirma: “Tu me perguntas qual é a diferença entre a concepção política de Hobbes e a minha. Respondo-te: a diferença consiste em que mantenho sempre o direito natural e que considero que o magistrado supremo, em qualquer cidade, só tem direitos sobre os súditos na medida em que seu poder seja superior ao deles; coisa que sempre ocorre no estado natural."

${ }^{28}$ CHAUÍ, Marilena. Política em Espinosa. São Paulo: Companhia das Letras, 2003. p. 289
} 
enquanto para o primeiro a política é uma forma de controlar esses impulsos do homem, de forma que eles não estejam em constante guerra pelo poder, para o segundo a política é uma forma de permitir que todos os homens exerçam seu desejo, ou seja, que todos possam governar. Por esse enunciado apenas, já começa a ficar claro porque Hobbes concebe um Estado que necessita de um soberano absolutista, enquanto Espinosa é um defensor da democracia absoluta.

\footnotetext{
"Os dois filósofos concebem a política como ação que pode ser objeto de uma ciência demonstrável oposta à utopia e à moralidade normativa (portanto, posto à concepção medieval da ciência prática como arte prudencial e normativa), e fundada no conhecimento das paixões humanas, surgindo, para Hobbes, como meio de controlar o desejo insaciável de mais poder, e, para Espinosa, como meio de dar vazão ao direito natural dos homens de governar e não ser governados, sem que se destruam uns aos outros." 29
}

Para entender porque essa diferença é tão fundamental para a tese dos dois autores, será necessário definir o que cada um deles entende por liberdade, através da teoria do conatusconforme concebida por cada um deles. Hobbes é um mecanicista e, como tal, tem uma visão da liberdade ancorada na noção de movimento. Para ele, liberdade corresponde à ausência de um obstáculo exterior. E essa força exterior, no caso, ao nos referirmos às liberdades individuais, é o poder soberano. Por outro lado, se o obstáculo ao movimento tiver uma causa interna, então não falaremos de falta de liberdade, mas de falta de poder. É por isso, por exemplo, que podemos falar que para Hobbes um escravo não tem falta de liberdade mas de poder, já que o seu limite é outro indivíduo, que também pertence à sociedade civil e não o soberano.

Assim, para Hobbes, as leis civis são um obstáculo ao direito natural. E aqui chegamos a um dos pontos centrais da discussão: dentro desse entendimento, é necessário um poder exterior para frear o Estado de Natureza. É impossível pensar em um soberano que está dentro da sociedade civil, dentro do pacto social, porque para Hobbes é necessário

\footnotetext{
${ }^{29}$ CHAUÍ, Marilena. Política em Espinosa. São Paulo: Companhia das Letras, p. 291
} 
que haja uma força externa fazendo oposição à força do Estado de

Natureza.

\begin{abstract}
"Em estado natural, o movimento é centrífugo (por isso desencadeia a sociabilidade insociável) e por isso deve encontrar limite ou obstáculo no movimento centrípeto, imposto pelas leis civis. Eis por que a passagem do direito natural ao direito civil é descrita como passagem do direito (liberdade) à lei da natureza (ditames da razão) e desta à lei civil (obrigação política). Em outras palavras, a passagem é uma sequencia de imposições de obstáculos ou de limites externos ao movimento natural, tendo como ponto culminante a Pessoa Artificial ou o Estado que, por ser artifício e artefato, é exterior ao natural." ${ }^{30}$
\end{abstract}

Por outro lado, Espinosa não pensa na liberdade como movimento linear, como velocidade, mas sim como intensidade, força, aceleração. Primeiramente, é preciso entender o que é um corpo para Espinosa. Para ele, um corpo (complexo) será o conjunto de outros corpos (simplíssimos) que se associam através de uma relação de proporcionalidade entre movimento e repouso. E é essa proporção entre movimento e repouso que irá definir a interação de um corpo com o exterior e mesmo com as diversas singularidades que o compõe. O conatus, por sua vez, será o esforço de um corpo por se conservar e, por isso, ele não será baseado na velocidade, mas sim por essas variações entre movimento e repouso que ocorrem dentro de um $\operatorname{corpo}^{31}$.

\footnotetext{
${ }^{30}$ Ibid., p. 304

${ }^{31}$ Sobre o tema, deve-se remeter à proposição 13 da Segunda Parte da Ética de Espinosa, em especial ao seguinte trecho: "Vemos, assim, em que proporção um indivíduo composto pode ser afetado de muitas maneiras, conservando, apesar disso, sua natureza. Até agora, entretanto, concebemos um indivíduo que se compõe tão-somente de corpos que se distinguem entre si apenas pelo movimento e pelo repouso, pela velocidade e pela lentidão, isto é, que se compõe de corpos mais simples. Se, agora, concebemos um outro indivíduo, composto de vários indivíduos de natureza diferente, veremos que também ele pode sr afetado de muitas maneiras, conservando, apesar disso, sua natureza. Pois, como cada uma de suas partes compõe-se de vários corpos, cada uma delas poderá, portanto, (pelo lema prec.), sem qualquer mudança de sua natureza, mover-se ora mais lentamente, ora mais velozmente e, como consequência, transmitir seus movimentos às outras partes, ora mais lentamente, ora mais velozmente. Se concebemos, além disso, um terceiro gênero de indivíduos, compostos de indivíduos do segundo gênero, veremos que também ele pode ser afetado de muitas maneiras, sem qualquer mudança de forma. E se continuarmos assim, até o infinito, conceberemos facilmente que a natureza inteira é um só indivíduo, cuja partes, isto é, todos os corpos, variam de infinitas maneiras, sem qualquer mudança do indivíduo inteiro." (SPINOZA, Benedictus de. Ética; tradução e notas de Tomaz Tadeu - 2. ed., Belo Horizonte: Autêntica Editora, 2008. pp. 103-105), e os postulados que a seguem.
} 
Assim, dessa definição de conatus, podemos extrair mais duas diferenças com Hobbes: primeiro, o conatusnão se baseia no desejo de ter sempre mais, um movimento linear que não quer ser refreado por nenhum obstáculo externo, mas sim em um esforço de conservação, ou seja, não está se falando em velocidade, mas em constância, em manutenção; depois, no caso de Espinosa, deve-se reconhecer que o conflito não existe apenas no exterior, mas também no interior de um corpo.

E mais uma observação a ser feita: para Espinosa, as partes que compõem o corpo complexo podem ser fortes ou fracas em relação ao conatus. São fracas as partes que não conseguem resistir às forças externas; são fortes aquelas que não só não são destruídas pelas exterioridades, como também podem ser fortalecer através delas. Assim, a potência do conatusdepende, primariamente, de conseguir fazer com que suas partes fortes superem suas partes fracas, para assim, portanto, ser capaz de superar os obstáculos exteriores.

\begin{abstract}
"Embora o conceito espinosano de liberdade implique, como o de Hobbes, a inexistência de coação ou de constrangimento externo e embora pressuponha, como em Hobbes, a autodeterminação diante de obstáculos externos, entretanto, não se define pela ausência de constrangimento, mas pela potência interna de agir quando esta é mais forte do que a potência das causas externas." 32
\end{abstract}

Assim, esse será um ponto importante para o resto desse trabalho: para Espinosa, a liberdade não é definida pela falta de obstáculos exteriores, mas pela capacidade de um corpo de conservar sua potência mesmo diante de tais obstáculos. E essa potência, por sua vez, deve ser entendida como o produto da relação entre as diversas partes que formam esse corpo. Portanto o que temos aqui é uma definição de liberdade que tem uma causa interna, já que depende do fortalecimento das partes fortes em detrimento das partes fracas.

Além disso, deve-se acrescentar que quando as partes fracas predominam, diremos que o corpo está agindo pela paixão. Agir pela paixão

\footnotetext{
${ }^{32}$ CHAUÍ, Marilena. Política em Espinosa. São Paulo: Companhia das Letras, 2003, p. 311
} 
significa que o conatusé causa inadequada daquele agir ou, em outras palavras, que o corpo está sendo determinado pelas forças externas. De modo oposto, quando as partes fortes predominam, dizemos que o corpo está agindo pela ação, ou seja, o conatusé a causa adequada, o que significa dizer que o que está motivando aquele agir são forças internas ao corpo. Assim, podemos dizer que um corpo será livre quando estiver na atividade (relativo à ação, oposto à passividade, que se refere à paixão), já que será causa adequada de si. Mas é importante lembrar que a diferença entre a passividade e a atividade não é a existência de relação com causas externas, já que esta está presente em ambas, mas na forma como ocorre essa relação.

\footnotetext{
"A passividade decorre do modo como a relação com o exterior se estabelece, da mesma maneira que a atividade não decorre de uma ausência de relação com algo externo e sim do modo como a relação se estabelece: na primeira, somos determinados a existir, operar, sentir e pensar segundo a força de um desejo externo interiorizado; na segunda, o que somos, pensamos, desejamos, sentimos e fazemos determina como nos relacionamos com a exterioridade. A liberdade é atividade corporal e psíquica de uma causa eficiente interna forte." 33
}

O que poderá ser extraído dessas duas concepções distintas de liberdade é, portanto, que para Hobbes, dentro de uma sociedade civil, não é possível falar em liberdades individuais (na verdade, a liberdade individual ainda existe, mas apenas na esfera privada, ou seja, na parte da vida social que não foi delegada ao comando do soberano), mas apenas em liberdades políticas, já que a vontade dos indivíduos está submetida ao soberano, ou seja, há um obstáculo externo limitando a liberdade. Já para Espinosa, uma sociedade civil é livre na medida em que o corpo político que a constitui esteja agindo na atividade, ou seja, que haja uma amplificação das partes fortes que compõem esse corpo de forma a possibilitar que ele não seja anulado pelas forças externas. Isso significa dizer que um Estado será tanto mais livre quanto o forem os cidadãos (partes) que o compõem e isso irá ocorrer se esses indivíduos forem capazes de exercer seu conatus.

\footnotetext{
${ }^{33} I b i d .$, p. 311
} 
Assim, voltamos ao ponto inicial: para Espinosa, o direito natural permanece dentro da sociedade civil, enquanto para Hobbes, não. Nesse sentido, pode-se dizer que o direito natural irá existir enquanto for possível o exercício da liberdade individual, enquanto houver a manifestação do conatus. Portanto, o que acontece em Hobbes é que, dentro da sociedade civil, o direito natural só subsiste de duas formas: nas relações pessoais, como vimos anteriormente, nessa parcela que não foi transferida para o soberano; e também em uma forma latente, em que ele apenas volta a ser exercido no caso de uma guerra civil, ou seja, quando o conatusfor bloqueado tão intensamente pelo direito civil que explode a guerra.

\footnotetext{
"Após o advento do direito civil, o direito natural é conservado por Hobbes de duas maneiras. Em primeiro lugar, como aquilo que permanece na qualidade de direito individual por não ter sido transferido por nenhum pacto ou em virtude do silêncio das leis. Em segundo lugar, o direto natural permanece na condição de virtualidade ou de inclinação latente que, em determinadas circunstâncias, pode vir a atualizar-se, como é o caso da guerra civil. O direito natural, portanto, é algo operante no interior da vida social, mas não possui realidade alguma para a vida política propriamente dita (a não ser no caso-limite da guerra civil e da renúncia do soberano, com a qual os súditos regressam à liberdade natural)." ${ }^{34}$
}

Para Espinosa, a relação entre sociedade civil e direito natural se dá de uma forma muito diferente. O que Hobbes considera como conservação do direito natural, não pode ser considerado como tal em Espinosa. Como vimos, para ele, o conatus, a potência, só pode ser exercido em relação a uma força externa, seja para ser destruído por esta (passividade) ou para se modificar e crescer a partir dessa (atividade). Dessa maneira, falar em direito natural no Estado de Natureza seria uma abstração para o autor, pois em um estado no qual todos podem tudo, não há uma resistência a ser oferecida capaz de caracterizar a atividade ou a passividade desse conatus. De forma que, uma vez instituída a sociedade civil, o direito natural se manifesta como potência dos indivíduos frente ao direito civil. Em outras palavras: o direito só existe para Espinosa quando ele é exercido, não há

\footnotetext{
${ }^{34}$ Ibid., p. 296
} 
que se falar em um direito natural latente; mas para que possa haver o exercício desse direito, é preciso que haja uma sociedade.

\begin{abstract}
"Em estado de Natureza, o direito natural é abstrato porque se encontra separado das condições de sua efetivação concreta, pois todos podendo tudo (visto não haver leis determinando o permitido e o proibido), na realidade ninguém pode coisa alguma. A vida política surgirá para que o direito natural se concretize e por essa razão ela não poderá suprimi-lo nem apenas conservá-lo como resíduo ou virtualidade. Espinosa conserva o direito natural tomando-o como medida do direito civil. A potência da soberania será o direito natural coletivo positivado no direito civil e será avaliada pela potência natural dos cidadãos, isto é, por seu direito natural individual." 35
\end{abstract}

Assim, só nos resta falar como se dará a distribuição do poder para Espinosa, já que ele claramente se opõe a visão de Hobbes de que, uma vez constituída a sociedade civil, o poder é delegado para um soberano que passará a atuar como forma de limitar os cidadãos daquela sociedade. Primeiramente, é preciso lembrar que um corpo, para Espinosa, é formado pela relação e interação das diferentes partes que o compõem. Desse modo, podemos dizer que ainda no Estado Natural a interação dos indivíduos, que são todos partes da Natureza, constitui um corpo único, chamado de multidão, e esse corpo, portanto, irá ser a base do Estado, na medida em que passe a atuar não mais como uma potência individual, mas como uma potência coletiva. Importante destacar que não há um pacto: é a interação dos indivíduos que forma um corpo único e esse corpo terá uma potência coletiva própria, que não corresponde à soma das potências individuais, mas sim à relação entre elas.

Uma vez formada a sociedade civil, duas normas poderão ser observadas: primeiro, a potência coletiva será sempre inversamente proporcional as potências individuais, ou seja, quanto mais força tiver um indivíduo isoladamente, menos força terá a multidão; a segunda norma, semelhante a primeira, é que a potência dos governantes deverá ser inversamente proporcional a dos cidadãos e estes deverão ter sempre mais potência que aqueles.

\footnotetext{
${ }^{35}$ Ibid., p. 297
} 
"Uma potência não é uma potencialidade, um possível virtual. Só é potência se for atual, pois só existe o que é atual. Um direito que não se exerça é um poder que não existe. Espinosa (...) não admitirá que o poder da Cidade seja ilimitado nem que seus limites sejam aqueles apontados por Hobbes, mas dirá que o direito da Cidade irá até onde for seu poder para exercê-lo. O limite, portanto, encontrase no direito natural dos cidadãos, uma vez que o poder soberano se mede pela relação inversamente proporcional que mantém com o deles." ${ }^{36}$

E é por tudo acima exposto que podemos afirmar, enfim, que a democracia é a forma mais natural de governo para Espinosa, porque nela, na medida em que todos são governantes e ninguém é (apenas) governado, a potência coletiva é exercida em sua forma mais amplificada, correspondendo a própria força do direito natural. Assim, respondendo a pergunta de por que a democracia é o "mais natural dos regimes" para Espinosa, Marilena Chauí afirma:

"Em primeiro lugar, porque nela todos sendo, de direito e de fato, legisladores, cidadãos súditos e governantes, permanecem livres e iguais, como eram em estado natural, e a potência coletiva é absolutamente proporcional ao direito natural, conservando a incomensurabilidade da soberania. Em segundo lugar, porque é a única forma política capaz de realizar o desejo natural de todos os homens, qual seja, governar e não ser governado." ${ }^{" 37}$

${ }^{36}$ Ibid., p. 302

${ }^{37}$ Ibid., p. 300 


\title{
3. RANCIÈRE E O DESENTENDIMENTO
}

\subsection{Conceitos Básicos}

Nesse capítulo, iremos discorrer sobre a tese do poder constituinte tal como apresentada por Jacques Rancière. O autor, de influência claramente marxista, baseia seu conceito de política na disputa de classes.

Assim, o autor divide a sociedade em dois grupos: aquele formado pela classe dominante,seja esta os burgueses, os patrícios, os nobres, etc. e a classe que não está no poder, a classe do resto, que pode ser representada pelos operários ou pelos plebeus, por exemplo. Rancière caracteriza esta classe como a "parcela dos sem parcela", ou seja, este grupo se diferencia do primeiro pelo fato de que a eles não é conferida nenhuma prerrogativa na sociedade em que estão inseridos, além do fato de serem livres. Por esse aspecto, inclusive, essa classe, o povo ou o demos, é formada por um grupo melífluo, composto por vários tipos diferentes.

\begin{abstract}
"O povo nada mais é que a massa indiferenciada daqueles que não têm nenhum título positivo - nem riqueza, nem virtude - mas que, no entanto, têm reconhecida a mesma liberdade que aqueles que o possuem. A gente do povo é de fato simplesmente livre como os outros.

Ora, é dessa simples identidade com aqueles que, por outro lado, lhes são em tudo superiores que eles tiram um título específico. O demos atribui-se, como sua parcela própria, a igualdade que pertence a todos os cidadãos; $\mathrm{E}$, com isso, essa parte que não é parte identifica sua propriedade imprópria com o princípio exclusivo da comunidade., e identifica seu nome - o nome da massa indistinta dos homens sem qualidade - com o nome da própria comunidade. Isso porque a liberdade - que é simplesmente a qualidade daqueles que não têm nenhuma outra (nem mérito, nem riqueza) - é ao mesmo tempo contada como a virtude comum." 38
\end{abstract}

Desse modo, o autor continua a descrever uma sociedade tal como ela se encontra em um momento qualquer. Para ele, enquanto não há disputa pelo poder, quando há um equilíbrio na relação entre a classe

\footnotetext{
${ }^{38}$ RANCIÈRE, Jacques. O Desentendimento - política e filosofia; tradução de Ângela Leite Lopes - São Paulo: Ed. 1. Editora 34, 1996, pp.23, 24
} 
dominante e o povo, esta se encontra no que ele chama de "estado de polícia”, um momento diametralmente oposto à política:

\begin{abstract}
"A política é, na sua essência, a lei, geralmente implícita, que define a parcela ou a ausência de parcela das partes. Mas, para definir isso, é preciso antes definir a configuração do sensível na qual se inscrevem umas e outras. A polícia é assim, antes de mais nada, uma ordem dos corpos que define as divisões entre os modos do fazer, os modos de ser e os modos do dizer, que faz que tais corpos sejam designados por seu nome para tal lugar e tal tarefa; é uma ordem do visível e do dizível que faz com que essa atividade seja visível e outra não o seja, que essa palavra seja entendida como discurso e outra como ruído.(...) A polícia não é tanto uma 'disciplinarização' dos corpos quanto uma regra de seu aparecer, uma configuração das ocupações e das propriedades dos espaços em que essas são distribuídas." 39
\end{abstract}

Pelo trecho acima, deve-se observar que ao identificar o conceito de "polícia" com o poder constituindo, o definindo como as forças e os mecanismos responsáveis pela manutenção do status quo dentro de um determinado corpo social, o autor rompe com o senso comum, que costuma atribuir à política essa função. Para Rancière, pelo contrário, a política é um momento de ruptura com a ordem pré estabelecida, na qual há uma redefinição na distribuição das parcelas dentro desse corpo social:

\begin{abstract}
"Proponho agora reservar o nome de política a uma atividade bem determinada e antagônica à primeira: a que rompe a configuração sensível na qual se definem as parcelas e as partes ou sua ausência a partir de um pressuposto que por definição não tem cabimento ali: a de uma parcela dos sem parcela. Essa ruptura se manifesta poro uma série de atos que reconfiguram o espaço onde as partes, as parcelas e as ausências de parcelas se definiam."
\end{abstract}

Assim, a política é a disputa por um espaço, uma nova proposta de partilha do sensível que deve necessariamente partir daqueles que não têm nenhuma participação nessa partilha, ou seja, aqueles que fazem parte da "parcela dos sem parcela". Para que tanto ocorra, é imprescindível a tomada de consciência por parte do povo de sua condição. Essa tomada de consciência se dá a partir daquilo que o autor denomina "dano", um evento que pode ou não se dar no espaço físico, possibilitando essa nova contagem

\footnotetext{
${ }^{39}$ Ibid., p. 42

${ }^{40}$ Ibid., p. 43
} 
das partes. Ainda é preciso destacar que, para o autor, a política ocorre quando se estabelece a disputa pelo espaço compartilhado pelas partes dos com parcela e a dos sem parcela.

O que se pode deduzir desse conceito, portanto, é que a política não é um fator constante ou permanente, mas pelo contrário, esporádico e raro. Assim, podemos identificar a política com o poder constituinte, pois ela nada mais é do que o processo de formação de uma nova ordem. Também se deve ressaltar que, como destaca o autor, "Nenhuma coisa é então por si política. Mas qualquer coisa pode vir a sê-lo se der ocasião ao encontro das duas lógicas.” (p. 45).

Esse é um dos aspectos mais interessantes do conceito proposto por Rancière: ao identificar a política como a disputa entre duas partes, ele ao mesmo tempo restringe e amplia o seu alcance. Por um lado, a política deve deixar de ser entendida como um aspecto intrínseco a toda sociedade, pois ela apenas existirá se houver o conflito entre as partes; por outro lado, esse conceito realça o fato de que a política pode se dar em qualquer microcosmos onde existam duas partes em disputa.

O que se deve definir, portanto, é qual é o objeto dessa disputa capaz de caracterizar a política. Para Rancière é fundamental que haja uma identificação entre as partes para que possa haver o conflito e a identificação se dá pelo próprio objeto da disputa, qual seja, a partilha do sensível:

\footnotetext{
"Por desentendimento entenderemos um tipo determinado de situação da palavra: aquela em que um dos interlocutores ao mesmo tempo entende e não entende o que diz o outro. $\mathrm{O}$ desentendimento não é o conflito entre aquele que diz branco e aquele que diz preto. É o conflito entre aquele que diz branco e aquele que diz branco mas não entende a mesma coisa, ou não entende de modo nenhum que o outro diz a mesma coisa sobre o nome de brancura." 41
}

Assim, a razão desse desentendimento é exatamente determinar quem terá a posse do $\log o s$, ou seja, definir aqueles que ditarão as regras

\footnotetext{
${ }^{41}$ Ibid., p. 11
} 
dessa partilha. É essa disputa que está na base da política e o seu resultado será a redefinição da parcela dos com parcela e da parcela dos sem parcela.

"Há política porque o logos nunca é apenas a palavra, porque ele é sempre indissoluvelmente a contagem que é feita dessa palavra: a contagem pela qual uma emissão sonora é ouvida como palavra, apta a enunciar o justo, enquanto outra é apenas percebida como barulho que designa prazer ou dor, consentimento ou revolta." 42

O que Rancière denomina por política, portanto, é uma ruptura na ordem vigente, essa ordem mantida pela polícia. Essa ruptura se dá pelo dissenso, que é um desentendimento surgido entre as partes integrantes de uma sociedade quando se propõe uma nova partilha do sensível. Porém, para que possa haver esse desentendimento, essa nova proposta para a comunidade em que está inserida, é preciso que a parcela dos sem parcela se reconheça como tal, subjetivação essa que se dará pelo dano. São essas, assim, as condições para que se verifique a política na concepção do autor.

\begin{abstract}
"Assim o dissenso, antes de ser a oposição entre um governo e pessoas que o contestam, é um conflito sobre a própria configuração do sensível. Os manifestantes põem na rua um espetáculo e um assunto que não tem aí seu lugar. E aos curiosos que vêem esse espetáculo, a polícia diz: 'Vamos circular, não há nada para ver'. O dissenso tem assim por objeto o que chamo o recorte do sensível, a distribuição dos espaços privados e públicos, dos assuntos de que neles se trata ou não, e dos atores que têm ou não motivos de estar aí para deles se ocupar. Antes de ser um conflito de classes ou de partidos, a política é um conflito sobre a configuração do mundo sensível na qual podem aparecer atores e objetos desse conflito." 43
\end{abstract}

\title{
3.2. O Princípio da Igualdade
}

É importante destacar que Rancière parte de um pressuposto para chegar a sua ideia de desentendimento, a igualdade das inteligências:

\footnotetext{
${ }^{42}$ Ibid., p. 36

${ }^{43}$ RANCIÈRE, Jacques. O dissenso IN A Crise da Razão. Organizador Adauto Novaes - São Paulo: Companhia das Letras: Brasília, DF. Ministério da Cultura. Rio de Janeiro. Fundação Nacional de Arte, 1999, p. 373
} 
"Do fato de uma ordem ser compreendida por um inferior pode-se deduzir simplesmente que essa ordem foi bem dada, que quem ordena teve pleno sucesso no seu trabalho próprio e consequentemente quem recebe a ordem executará bem o seu trabalho que é um prolongamento daquele, de acordo com a divisão entre a simples aisthesise a plenitude da hexis. Mas também se pode deduzir uma consequência totalmente desconcertante: se o inferior compreendeu a ordem do superior, é que ele participa da mesma comunidade dos seres falantes, que é, nisso, seu igual. Deduz-se daí, em suma, que a desigualdade dos níveis sociais só funciona por causa da própria igualdade dos seres falantes." 44

Essa tese foi explicitada pelo autor em "O Mestre Ignorante", obra anterior ao "O Desentendimento". O livro, ainda que percebido principalmente como um trabalho sobre pedagogia, mostra sua faceta política ao propor uma disputa entre aqueles considerados superiores e inferiores, afirmando que os primeiros acreditariam ser vantajosa a manutenção na crença da desigualdade das inteligências ("A desigualdade não é a consequência de nada, ela é uma paixão primitiva; ou, mais exatamente, ela não tem outra causa, a não ser a igualdade." ${ }^{45}$ ).

A necessidade da manutenção dessa tese decorre de uma consequência do próprio princípio da igualdade: sendo todos iguais, não há uma razão lógica que possa definir aqueles que deverão governar ou aqueles que deverão ser governados. O que Rancière afirma é que essa escolha é baseada unicamente no acaso e a função do estado de polícia é o de prolongar essa situação pelo máximo de tempo possível. Dessa forma, quando se rompe a crença na desigualdade entre governados e governados, a sociedade começa a abrir caminho para que ocorra o dano, para que surja o dissenso.

\begin{abstract}
"A política se apoia neste fundamento paradoxal que é a ausência de todo fundamento da dominação. Num certo sentido, a razão última da política poderia se resumir num único axioma: ninguém possui título para governar. Não há título para governar. O poder não pertence ao nascimento ou â sabedoria, À riqueza ou à antiguidade. Não pertence a ninguém. Nenhuma propriedade específica distingue os que têm vocação para governar dos que têm vocação para ser
\end{abstract}

\footnotetext{
${ }^{44}$ RANCIÈRE, Jacques. O Desentendimento - política e filosofia; tradução de Ângela Leite Lopes - São Paulo: Ed. 1. Editora 34, 1996, p. 60

${ }^{45}$ RANCIÈRE. Jacques. O Mestre Ignorante - Cinco lições sobre a emancipação intelectual.

Traduzido por Lilian do Valle. Ed. 2. Belo Horizonte: Editora Autêntica, 2005. p. 116
} 
governados. A autoridade política não possui, em última instância, outro fundamento senão a pura contingência." ${ }^{46}$

Em suma, o que Rancière argumenta é que todos os seres humanos são radicalmente iguais. Mas ainda se mantendo no plano do individuo, o autor afirma que o que marca essa igualdade não é uma forma uniforme de expressão das inteligências, mas a habilidade que todos têm de absorver conhecimentos e expressá-los. É necessário, então, que haja a emancipação intelectual do indivíduo para que ele possa concretizar o potencial de sua inteligência, emancipação esta que nada mais é do que a tomada de consciência de sua real capacidade.

\begin{abstract}
“A emancipação é a consciência dessa igualdade, dessa reciprocidade que, somente ela, permite que a inteligência se atualize pela verificação. $O$ que embrutece o povo não é a falta de instrução, mas a crença na inferioridade de sua inteligência. E o que embrutece os 'inferiores' embrutece, ao mesmo tempo, os 'superiores'. Pois só verifica sua inteligência aquele que fala a um semelhante, capaz de verificar a igualdade das duas inteligências." 47
\end{abstract}

Assim, volta-se ao tema discutido inicialmente, Esse mesmo raciocínio deve ser aplicado para o conceito de "dano" que, para Rancière, está na base do desentendimento. Como ele afirma, o dano é uma nova contagem das partes, ele ocorre quando a parte que não possui as parcelas se dá conta de sua posição e a partir de um ou mais atos desafia a composição do corpo social em que está inserida. Como foi afirmado anteriormente: não há uma razão intrínseca que leve um indivíduo a governar e outro a ser governado, mas é preciso que os governados tenham ciência dessa igualdade para que eles possam reivindicar o posto de governantes.

O autor apresenta um caso ocorrido no julgamento do revolucionário Auguste Blanqui para exemplificar esse cenário. Blanqui, ao ser perguntado

\footnotetext{
${ }^{46}$ RANCIÈRE, Jacques. O dissenso IN A Crise da Razão. Organizador Adauto Novaes - São Paulo: Companhia das Letras: Brasília, DF. Ministério da Cultura. Rio de Janeiro. Fundação Nacional de Arte, 1999, p. 370

${ }^{47}$ RANCIÈRE. Jacques. O Mestre Ignorante - Cinco lições sobre a emancipação intelectual. Traduzido por Lilian do Valle. Ed. 2. Belo Horizonte: Editora Autêntica, 2005. p., p. 65
} 
sobre sua profissão, afirma ser um "proletário". O presidente do tribunal se recusa a admitir que esta seja uma profissão, ao que Blanqui responde que é "a profissão de trinta milhões de franceses que vivem de seu trabalho e que são privados de seus direitos políticos" 48 . O que Blanqui está afirmando, na verdade, é uma identificação entre todos esses franceses que não fazem parte da contagem da sociedade nesse momento. O que os une não é o trabalho realizado, mas o fato de que eles fazem parte da "parcela dos sem parcela" e a partir desse momento se reconhecem como tal. E é importante ressaltar que essa afirmação é ao mesmo tempo uma negação: ao se definirem como parte dos incontados, eles estão se “desidentificando" com aquele conjunto de indivíduos que antes compunham, de operários, trabalhadores, assalariados. Ao mesmo tempo que afirmam sua subjetivação, eles negam a partilha do sensível tal como dada. Está aí o dano.

\begin{abstract}
“"Demos' é o sujeito da identidade da parte e do todo. 'Proletário', ao contrário, subjetiva essa parcela dos sem-parcela que torna o todo diferente de si mesmo. Platão insurgia-se contra esse demos que é a contagem do incontável. Blanqui inscreve, sob o nome de proletários, os incontados no espaço em que são contáveis como incontados. A política em geral é feita desses erros de cálculo, é obra de classes que não classes, que inscrevem sob o nome particular de uma parte excepcional ou de um todo da comunidade (os pobres, o proletariado, o povo) o dano que separa e reúne duas lógicas heterogêneas de comunidade. (...) O dano é simplesmente o modo de subjetivação no qual a verificação da igualdade assume figura política." $" 49$
\end{abstract}

Pode-se, portanto, ser traçada uma linha do tempo imaginária na história das sociedades, a qual teria início no estado de polícia, durante o qual as partes da sociedade se encontram em um momento de não disputa e a desigualdade do corpo social não é percebida, ou não é contraposta à igualdade intrínseca à natureza humana; em um segundo momento, há o dano, a tomada de consciência dos "inferiores", na qual estes se percebem como um conjunto, uma classe, exatamente pelo fato de serem aqueles sem

\footnotetext{
${ }^{48}$ RANCIÈRE, Jacques. O Desentendimento - política e filosofia; tradução de Ângela Leite Lopes - São Paulo: Ed. 1. Editora 34, 1996, p. 49

${ }^{49}$ Ibid., p. 50, 51
} 
espaço na partilha das parcelas dessa sociedade. A partir desse momento, portanto, um novo elemento é integrado à dinâmica: enquanto no estado de polícia nós só podemos contar um grupo, aquele que tem todas as prerrogativas, agora nós temos dois grupos dentro do mesmo corpo social. Nesse momento, cessa o estado de polícia e inicia-se a política.

\begin{abstract}
“A subjetivação política produz um múltiplo que não era dado na constituição policial da comunidade, um múltiplo cuja contagem se põe como contraditória com a lógica policial. Povo é o primeiro desses múltiplos que desunem a comunidade dela mesma, a inscrição primária de um sujeito e de uma esfera de aparência de sujeito no fundo do qual outros modos de subjetivação propõem a inscrição de outros 'existentes', de outros sujeitos do litígio político. Um modo de subjetivação não cria sujeitos exnihilo. Ele os cria transformando identidades definidas na ordem natural da repartição das funções e dos lugares em instâncias de experiência de um litígio." ${ }^{50}$
\end{abstract}

O que é importante de se observar nesse ponto é que há uma contradição fundamental no conceito de política. Enquanto este está fundamentalmente baseado em uma igualdade radical entre todos os indivíduos pertencentes a um corpo social, o que ela procura afirmar é sempre uma desigualdade dentro desse mesmo corpo. A política, portanto, sempre aponta para seu próprio fim, porque enquanto para que esta possa ocorrer é imprescindível a igualdade entre as partes, ela só tomará lugar exatamente porque as partes são (ou melhor, estão) desiguais. E, mais ainda, no final do momento político, o que sempre resta é uma desigualdade, ainda que diferente da primeira. Enquanto as partes se encontrarem em uma posição de igualdade, haverá disputa pelo logos. Por sua vez, enquanto o logos estiver em disputa, haverá política. E a política, como vimos, é sempre um evento esporádico e temporário.

\footnotetext{
"Nenhuma coisa é em si política, pois a política só existe por um princípio que não lhe é próprio, a igualdade. O estatuto desse 'princípio' deve ser precisado. A igualdade não é um dado que a política aplica, uma essência que a lei encarna nem um objetivo que ela se propões atingir. É apenas uma pressuposição que deve ser discernida nas práticas que a põem em uso." ${ }^{11}$
}

\footnotetext{
${ }^{50}$ Ibid., p. 48

${ }^{51}$ Ibid., p. 45
} 
E, ainda:

"O paradoxo da emancipação intelectual nos permite pensar o nó essencial do logos com o dano, a função constitutiva do dano para transformar a lógica igualitária em lógica política. Ou a igualdade não causa nenhuma efeito na ordem social. Ou causa efeito sob a forma específica do dano. (...) A política é a prática na qual a lógica do traço igualitário assume a forma do tratamento de um dano, onde ela se torna o argumento de um dano principal que vem ligar-se a tal litígio determinado na divisão das ocupações, das funções e dos lugares."

Quando Rancière afirma que a igualdade é ao mesmo tempo o princípio fundador da política, mas estranha a ela, o que se pode concluir é que essa igualdade só pode ser observada a posteriori. Ocorre que esse momento no qual a igualdade está sendo afirmada é um momento anormal, no sentido de que qualquer forma de normatividade está suspensa. É o rompimento com a ordem anterior, no qual se busca a constituição de uma nova ordem. Enquanto houver a afirmação da igualdade das classes haverá o desentendimento fundamental à política, o logos estará em disputa. Contudo, sendo a política um estado raro em qualquer sociedade, esse momento irá se encerrar com a formação de uma nova ordem. Com a formação dessa nova ordem, também será constituída uma nova normalidade. Assim, a questão a ser formulada é quando se daria a anormalidade.

"Pode-se dizê-lo de outro modo: a política não advém naturalmente nas sociedades humanas. Advém como um desvio extraordinário, um acaso ou uma violência em relação ao curso ordinário das coisas, ao jogo normal da dominação. Esse jogo normal é a transição de um principio de dominação a outro. (...) A política advém nas sociedades como uma ruptura no processo de passagem de uma lógica da dominação a outra, do poder da diferença no nascimento ao poder indiferente da riqueza." $" 53$

Em seu texto "O Normal e o Patológico", Georges Canguilhem discorre sobre o tema. Ele propõe o normal como um conceito dinâmico. Assim, esse conceito se aproxima do conceito de logos apresentado por

\footnotetext{
${ }^{52}$ Ibid., p. 47

${ }^{53}$ RANCIĖRE, Jacques. O dissenso IN A Crise da Razão. Organizador Adauto Novaes - São Paulo: Companhia das Letras: Brasília, DF. Ministério da Cultura. Rio de Janeiro. Fundação Nacional de Arte, 1999, p. 371
} 
Rancière no sentido em que ele também está em disputa: cabe a um determinado grupo definir o que é o normal. Unificando os dois conceitos, portanto, pode-se dizer que o grupo que terá a posse do logos será aquele responsável por definir o normal. Para Canguilhem, isso significa uma escolha que marca o fim de um conflito, ou seja, quando uma sociedade define essa nova normalidade, se encerra a política e retorna-se ao estado de polícia, que nada mais é do que um modo de garantir o cumprimento de uma norma. Isso significa também que cada possibilidade de partilha do sensível implica em um novo conceito de normal.

\begin{abstract}
"Uma norma se propõe como um modo possível de unificar um diverso, de reabsorver uma diferença, de resolver uma desavença. No entanto, propor-se não é o mesmo que impor-se. Ao contrário de uma lei da natureza, uma norma não acarreta necessariamente seu efeito. Isto é, uma norma pura e simples não tem nenhum sentido de norma. A possibilidade de referência e de regulação que ela oferece contém - pelo fato de ser apenas uma possibilidade - a latitude de uma outra possibilidade que só pode ser inversa. Com efeito, uma norma só é a possibilidade de uma referência quando foi instituída ou escolhida como expressão de uma preferência e como instrumento de uma vontade de substituir um estado de coisas insatisfatório por um estado de coisas satisfatório." $" 54$
\end{abstract}

Canguilhem passa, então, a tentar definir quando se daria o anormal. Partindo do pressuposto de que o normal é uma escolha realizada por um determinado grupo que demonstra uma preferência por um estado de coisas, é necessário que algo preexista a esse momento. E esse estado de coisas anterior seria, portanto, um momento em que a experiência humana não é normatizada. Canguilhem compara esse momento a uma espécie de idade do ouro ou, como os contratualistas chamariam, o estado de natureza. Ocorre que, como o autor irá afirmar, não é possível que esse estado de coisas ocorra em nenhum tempo factível. Isso porque o anormal só pode existir como negação do normal, então, ainda que este necessariamente

\footnotetext{
${ }^{54}$ CANGUILHEM. Georges. O Normal e o Patológico; tradução de Maria Thereza Redig de Carvalhos Barrocas. Revisão Técnica de Jorge Alberto Costa e Silva. ed. 3, rev. e aumentada . Rio de Janeiro: Editora Forense Universitária, 1990. p. 212
} 
tenha que se localizar em um ponto anterior ao normal, só pode ser concebido posteriormente a ele.

“O anormal, enquanto a-normal, é posterior à definição do normal, é a negação lógica deste. No entanto, é a anterioridade histórica do futuro anormal que provoca uma intenção normativa. O normal é o efeito obtido pela execução do projeto normativo, é a norma manifestada no fato. Do ponto de vista do fato há, portanto, uma relação de exclusão entre o normal e o anormal. Esta negação, porém, está subordinada À operação de negação, à correção reclamada pela anormalidade. Não há, portanto, nenhum paradoxo em dizer que o anormal, que logicamente é o segundo, é existencialmente o primeiro." 55

De forma semelhante podemos conceber o conceito de igualdade para Rancière. O que o autor afirma é que a política irá acontecer no momento em que uma parcela da sociedade propõe uma nova contagem das parcelas. E isso ocorre porque alguém questionou o estado das coisas, se reconheceu (e reconheceu os outros em redor dele) como parte de um grupo social, da parcela dos sem parcela, e está propondo um novo estado das coisas. É o que aqui foi caracterizado como o dano.

Ocorre que esse momento, assim como o anormal de Canguilhem, só pode ser reconhecido posteriormente, pois como Rancière afirmou a igualdade não pertence a política. Se entendermos a política como o momento de formação de uma nova ordem, então já não estaremos mais vendo a igualdade, mas a criação de uma nova desigualdade e tudo que resta da ideia dessa igualdade é uma espécie de mito fundador da desigualdade futura. Ou seja, o fim da política se dá quando a afirmação da igualdade se transforma em negação da desigualdade.

"É inútil querer buscar modelos na era de Cronos e nos sonhos néscios dos reis pastores. Entre a era de Cronos e nós, a incisão do dano já está sempre passada. Quando se decide basear em seu princípio a proporção da polis, é que a democracia já passou por aí. Nosso mundo gira 'em sentido contrário' e quem quiser curar a política de seus males terá apenas uma solução: a mentira que inventa uma natureza social para dar à comunidade uma arkhé."

\footnotetext{
${ }^{55}$ Ibid.. p. 216

${ }^{56}$ RANCIÈRE, Jacques. O Desentendimento - política e filosofia; tradução de Ângela Leite Lopes

- São Paulo: Ed. 1. Editora 34, 1996, p. 30, 31
} 


\subsection{A Filosofia Política}

Para Rancière a questão fundamental da filosofia política é tentar suprir o lapso entre a igualdade que é princípio da política e a desigualdade que decorre desta. Em outras palavras, ela tenta aproximar a política e a polícia, a lógica policial e a lógica igualitária. $\mathrm{O}$ autor afirma então que há três grandes figuras na filosofia política: a arqui-política, a para-política e a meta-política.

A arqui-política pode ser identificada com as ideias apresentadas por Platão na "República". O seu objetivo é impedir qualquer forma de subjetivação política ao predeterminar uma completa divisão dos espaços. Assim, o que antes seria a simples liberdade do povo passa a ser sua aptidão. Cada cidadão tem seu lugar na comunidade estritamente definido pelo seu ofício, negando-se o espaço comum a ser disputado que é necessário para a constituição do dano. Com isso, o que se pretende é corrigir o paradoxo da parcela dos sem parcela. Ao se designar um espaço para cada indivíduo dentro da sociedade busca-se evitar o conflito, impedir o dano. Mas assim sendo, o resultado final acaba por ser a supressão da própria política.

\footnotetext{
"A arqui-política, da qual Platão dá a fórmula, resume-se assim na realização integral da physis em nomos. Isto supõe a supressão dos elementos do dispositivo polêmico da política, sua substituição pelas formas de sensibilização da lei comunitária. A substituição de um título vazio - a liberdade do povo - por uma virtude igualmente vazia - a sophrosyné dos artesãos - é o ponto nodal desse processo. A supressão total da política enquanto atividade específica é seu resultado. ${ }^{\text {57 }}$
}

A para-política, por sua vez, que tem seu princípio nas teses aristotélicas, não irá negar a existência do conflito. Reconhecendo sua existência, o que ela faz é procurar inscrever esse conflito dentro da ordem constitucional, transformar a disputa de poder em uma parte da ordem policial. Aristóteles procura conciliar duas lógicas antagônicas: aquela que

${ }^{57}$ Ibid., p. 78 
prioriza o mando do melhor como o melhor para as sociedades e aquela que reconhece a necessidade de se conservar a igualdade entre as partes. Assim, para ele, a única solução é um rodízio de poder, ou seja, um simulacro do conflito político regido pelas leis da sociedade. Ocorre que, mais uma vez, ao tentar identificar a ordem política com a ordem policial, o que acaba por se observar é a negação da política. A diferença entre a arqui-política e a para-política é, portanto, que enquanto a primeira propõe uma ordem constitucional que anule a possibilidade do conflito, a segunda propõe uma ordem constitucional que inscreve o conflito dentro dela. Em ambos os casos, o resultado final é uma completa identificação entre a política e a polícia, que acaba por negar aquela.

“Se a 'filosofia política' platônica e seus sucedâneos propõem curar a política substituindo as aparências litigiosas do demos pela verdade de um corpo social animado pela alma das funções comunitárias, a filosofia política aristotélica e seus sucedâneos propõem a realização da ideia do bem pela exata mimésis do distúrbio democrático que obsta a sua efetuação: utopia última de uma política sociologizada, invertida em seu contrário; fim calmo da política em que os dois sentidos do 'fim', o telos que se realiza e o gesto que suprime, acabam por coincidir de maneira exata." ${ }^{, 58}$

Mas a para-política ainda tem uma manifestação moderna, tal qual como proposta pelos contratualistas. As partes alienam completamente sua liberdade e a soberania, ao invés de ser um objeto de disputa, passa a estar concentrada em um não-lugar para as partes. Assim, não há mais conflito entre as partes da sociedade, que passam a ser um bloco único, o dos indivíduos, se opondo ao poder do Estado. Nesse caso, o problema é que ao tentar se afirmar a igualdade na sociedade, o que se propõe é sua total alienação.

O que ocorre, assim, é que "povo" ganhará um significado duplo: irá se referir tanto ao àqueles que alienaram sua soberania, se transformando em uma massa não identificável de indivíduos, quanto ao povo da parcela

\footnotetext{
${ }^{58}$ Ibid., p. 83
} 
dos sem parcela. O termo "povo", portanto, passa a identificar a distância da arqui-política e da política.

\begin{abstract}
"Denunciando os compromissos da para-política aristotélica com a sedição que ameaça o corpo social e decompondo o demos em indivíduos, a para-política do contrato e da soberania reabre uma distância mais radical do que a velha distância política da parte tomada pelo todo. Ela dispõe a distância do homem a si mesmo como o fundo primeiro e último da distância do povo a si mesmo.

"Pois ao mesmo tempo que o povo da soberania, apresenta-se seu homônimo, que não se parece em nada com ele, que é a denegação ou o escárnio da soberania, o povo pré-político ou fora-do-político que se chama população ou populhacho: população laborioso e sofredora, massa ignorante, turba acorrentada ou desacorrentada etc., cuja factualidade entrava ou contradiz a realização da soberania." 59
\end{abstract}

E, assim, chega-se à meta-política. A meta-política tem como objetivo destacar exatamente a diferença entre a política e a mentira constitutiva desta, entre a igualdade exposta pelo conflito e a desigualdade que é tanto início quanto fim dela. É um conceito formulado por Marx para atacar a "ilusão democrática" como forma de efetivação da política.

O termo "classe" é exemplar para expor essa diferença. Classe enquanto subscrita à ordem policial pode significar uma casta, aproximando-se do conceito proposto pela arqui-política platônica. Enquanto parte do político, porém, classe é um modo de subjetivação de uma determinada parte da sociedade. Pode-se se remeter ao exemplo anteriormente citado do julgamento do revolucionário Blanqui e do proletariado: no sentido político, classe é aquela da luta de classes, aquela que inicia o conflito.

O termo "classe" significa tanto a verdade da meta-política, enquanto fator da luta de classes, parte constitutiva do social, como a mentira desta, no sentido da incorporação da política pela polícia. Para lidar com essa diferença, Marx cunha o termo "ideologia". Ideologia é a verdade forjada pela mentira da política. É a palavra que transforma o conflito em ilusão, aquela que está no momento exato da esvaziamento da política. É, portanto, para retomar os conceitos propostos por Canguilhem, o ponto em que o

\footnotetext{
${ }^{59}$ Ibid., p. 88
} 
normal se debruça sobre o anormal reconhecendo sua existência apenas como "mito fundador".

"É em suma o conceito onde toda política se anula, seja por sua evanescência proclamada, seja, ao contrário, pela afirmação de que tudo é político, o que significa dizer que nada o é, que a política é apenas o modo parasitário da verdade. Ideologia é, definitivamente, o termo que permite sempre deslocar o lugar do político até seu limite: a declaração de seu fim. (...) No final do processo, o dano, depois de ter passado pelo abismo de sua absolutização, é trazido de volta à iteração infinita da verdade da falsidade, à pura manifestação de uma verdade vazia. A política que ele fundava pode então ser identificar-se ao inatingível paraíso original onde indivíduos e grupos utilizam a palavra, que é próprio do homem, para conciliar seus interesses particulares no reino do interesse geral. ${ }^{, 60}$

Assim, resta-nos falar dessa forma de democracia que é objeto da análise da filosofia política. Rancière irá denominá-la de “democracia consensual". A política dos filósofos nos remete a um movimento circular em que o fim do conflito nos leva a um momento anterior a este conflito constitutivo da política. Como o autor irá determinar "A volta 'filosófica' da política e seu 'fim' sociológico são uma única e mesma coisa"61. E esse fim sociológico da política é que pode ser chamado de "democracia consensual"'.

A primeira preocupação do autor será a de esclarecer porque os termos "democracia" e "consenso" são, em suas origens, excludentes. Assim, ele passará a descrever as condições para a existência de uma real democracia. A democracia deve ser concebida como uma interrupção da ordem policial, uma forma de subjetivação política. Assim, o povo da democracia tem que ser capaz de realizar a nova contagem das partes, se reconhecer como a parcela dos sem parcela. Para tanto, não será possível conceber esse povo como aquele da arqui-política. Por fim, para que ocorra a democracia, é necessário que exista o litígio político, o conflito sobre a contagem das partes na sociedade.

\footnotetext{
${ }^{60}$ Ibid., p. 93

${ }^{61}$ Ibid., p. 98
} 
Por seu lado, a pós-democracia ou democracia consensual se dará em um momento após esse conflito. Ressalte-se que esse momento não irá significar uma divisão perfeita do corpo social, mas sim uma divisão previamente definida. É a concretização do projeto da arqui-política, no qual o conflito é totalmente esvaziado por uma completa ocupação do espaço sensível. A democracia consensual significa assim o desaparecimento da política e, por isso, é oposta a democracia "real".

"Mas, para que as partes discutam em vez de lutar, é preciso primeiramente que
existam como partes, tendo de escolher entre duas maneiras de obter sua parcela.
Antes de ser a preferência dada à paz sobre a guerra, o consenso é um certo
regime do sensível. É o regime em que as partes já estão pressupostamente dadas,
sua comunidade constituída e o cálculo de sua palavra idêntica à sua performance
linguística. O que o consenso pressupõe portanto é o desaparecimento de toda
distância entre a parte de um litígio e a parte da sociedade. É o desaparecimento
do dispositivo da aparência, do erro de cálculo e do litígio abertos pelo nome do
povo e pelo vazio de sua liberdade. É, em suma, o desaparecimento da política."

Para Rancière, esse é o estado em que se encontram as sociedades pós-modernas. A pós-democracia se baseia em uma mentira de igualdade, na qual a contagem das partes é sempre exata. E a forma de realização dessa “igualdade" se dá por uma "ciência da opinião" que faz com que a soma destas corresponda perfeitamente ao interesse comum. É uma simulação que concretiza a arqui-política: a opinião de cada indivíduo deve ser apurada e corresponder exatamente ao lugar que este ocupa dentro da sociedade.

O litígio político é transformado então em um problema jurídico, no qual cabe ao juiz determinar o espírito das leis, o que está de acordo com a constituição de daquela sociedade. Ele é o responsável por determinar o princípio da igualdade. Assim, suprime-se de vez o conflito: o Estado passa a ser o gestor do desentendimento e o direito deve ser sua ferramenta para garantir a uniformização da comunidade.

\footnotetext{
${ }^{62}$ Ibid., p. 105
} 
"De um lado, o direito vem libertar o Estado da política da qual ele libertou o povo; do outro, ele vem colar-se a toda situação, a todo litígio possível, decompôlo nos elementos de seu problema, e transformar as partes do litígio em atores sociais, refletindo como a lei de seu agir a identidade da comunidade consigo mesma. (...) $\mathrm{O}$ direito e o fato tornam-se tão indiscerníveis quanto a realidade e sua imagem, quanto o real e o possível. O Estado perito suprime todo intervalo de aparência, de subjetivação e de litígio na exata concordância da ordem do direito com a ordem dos fatos. ${ }^{\circ 3}$

Essa lógica, quando expandida à comunidade internacional, se transforma no que Rancière denomina de "era humanitária". Essa seria a aplicação do sistema internacional entre os Estados, que tem início com a derrocada dos Estados totalitários em uma Europa pós Segunda Guerra. Nesse cenário, apenas é possível pensar um mundo formados por indivíduos que manifestem somente sua humanidade em comum. São negadas as diferenças de cultura, de etnia, em nome de uma harmonia pertencente ao mundo do consenso, ao mundo do direito.

Mais uma vez, a negação do dano leva a sua absolutização, à criação de uma "vítima universal" a quem é dada a prerrogativa dos "direitos humanos". Nesse sentido, o sujeito desses direitos só pode ser o indivíduo genérico, indiferenciado. Não é mais possível que ninguém reivindique para si esse lugar de vítima, ele apenas poderá recair na humanidade como um todo. É, enfim, a expropriação total do logos, a negação da própria humanidade. A vítima absoluta impede o dano. E assim se dá, portanto, através da universalização do consenso, o fim definitivo da política.

"Há uma polícia mundial e ela pode às vezes proporcionar alguns bens. Mas não há política mundial. $\mathrm{O}$ 'mundo' pode expandir-se. O universal da política, por sua vez, não se expande. Continua sendo a universalidade da construção singular dos litígios, a qual não tem nada a esperar, nem da essência encontrada de uma mundialidade mais essencialmente 'mundial', nem da simples identificação do universal ao reino da lei. (...) A política, na sua especificidade, é rara. É sempre local e ocasional. Seu eclipse atual é bem real e não existe mais ciência política capaz de definir seu futuro que ética da política que faria de sua existência o único objeto de uma vontade. A maneira como uma política nova poderia quebrar o círculo da consensualidade feliz e da humanidade denegada não é hoje nem predizível nem decidível." ${ }^{64}$

\footnotetext{
${ }^{63}$ Ibid., p. 114
}

${ }^{64}$ Ibid., p. 138 


\section{NEGRI E A CRISE DA MODERNIDADE}

\subsection{Conceitos Básicos}

Já no início do primeiro capítulo de sua obra "O Poder Constituinte", Negri nos apresenta o problema que será enfrentado ao longo de toda a sua obra: "o poder constituinte resiste à constitucionalização" 65 . Mas para que se chegue ao significado dessa afirmação, será preciso inicialmente compreender o que o autor entende por poder constituinte e quais são as problemáticas atreladas a esse conceito.

Ele critica a teoria vigente da ciência jurídica, que resume o poder constituinte ao poder de organizar uma Constituição e definir as normas fundamentais ao Estado. Para o autor, o poder constituinte se identifica com a própria política, no sentido em que ele não deve ser entendido unicamente como a fonte da produção de normas, mas também como o sujeito destas.

\footnotetext{
"Falar de poder constituinte é falar de democracia. Na era moderna, os dois conceitos foram quase sempre correspondentes e estiveram inseridos num processo histórico que, com a aproximação do século XX, fez com que se identificassem cada vez mais. Em outros termos, o poder constituinte não tem sido considerado apenas a fonte onipotente e expansiva que produz as normas constitucionais de todos os ordenamentos jurídicos, mas também o sujeito desta produção, uma atividade igualmente onipotente e expansiva. Sob este ponto de vista, o poder constituinte tende a se identificar com o próprio conceito de politica, no sentido com que este é compreendido numa sociedade democrática. ${ }^{, 66}$
}

Deve-se ressaltar que o autor refere-se sempre ao poder constituinte como onipotente e expansivo. E para explicitar o que ele está propondo com isso, ele diferencia três teses sobre o tema: o poder constituinte como transcendente ao poder constituído; como imanente ao poder constituído; e como fonte integrada do sistema constitucional.

\footnotetext{
${ }^{65}$ NEGRI, Antonio. O Poder Constituinte - ensaio sobre as alternativas da modernidade; tradução de Adriano Pilatti - Rio de Janeiro: Ed. 1, DP\&A, 2002. p. 7

${ }^{66}$ Ibid., p. 7
} 
Sobre o primeiro grupo, bastante já foi dito. É a teoria tradicional da ciência jurídica, aquela que acredita que o poder constituinte funda uma nova sociedade para imediatamente romper todos os laços que a unem a esta. Assim, o único objetivo do poder constituinte seria a formulação das normas jurídicas fundamentais, ou seja, estaria intrinsecamente ligado a sua autolimitação. Ele afirma que, nesse sentido, "a transcendência do poder constituinte é a sua negação",67.

Por outro lado, Negri também não se satisfaz com as consequências de se pensar o poder constituinte simplesmente como imanente ao sistema jurídico-constitucional. Ele admite que o grau de imanência pode variar, mas que em todos os casos, o resultado é que o poder constituinte acaba limitado pelo sistema que ele deveria impulsionar. Por exemplo, ele afirma que para Rawls, exemplo de teoria que pensa um grau mínimo de imanência, o poder constituinte estaria no segundo de quatro estágios do processo de formação política e, em consequência, a sua imanência seria apenas uma forma de reabsorvição do poder constituinte pelo poder constituído, limitando aquele as regras deste, já que o processo de formação de um acordo consensual contratual sobre os princípios de justiça limitaria o poder constituinte.Também pensando em um grau maior de imanência, como no caso de Lassalle e Heller, que acreditam que o sistema jurídicoconstitucional deve se adequar as normas da realidade instituídas pelo poder constituinte, há uma absorção do poder constituinte pelo Estado, no sentido em que o processo de constitucionalização é entendido como uma instância de intermediação entre essas normas da realidade e as normas jurídicas.

Por fim, resta considerar a tese segundo a qual o poder constituinte está integrado ao poder constituído. Assim, o que caracteriza essas teorias é o fato delas perceberem uma normatividade intrínseca ao próprio elemento histórico. A formação da norma deixa de ser um evento único para se tornar parte da elaboração do próprio sistema jurídico em que ela está inserida. Também aqui há uma variação de grau, mas pode-se dizer que para aqueles

\footnotetext{
${ }^{67}$ Ibid., p. 14
} 
teóricos que pensam uma integração mais ampla, a constituição formal será sempre submetida a uma constituição material, sendo esta formada pelo conjunto das forças políticas desta sociedade. Mas aqui também se observa a limitação do poder constituinte, que passaria a ser delimitado pelas forças políticas no poder. Pensar em um poder constituinte pré-concebido afastaria tanto seu caráter dinâmico como seu caráter absoluto; determiná-lo pelas forças políticas no poder o afasta da multidão.

Também se atendo ao constitucionalismo tradicional não se encontram resultados melhores, pelo contrário: o constitucionalismo é, por essência, a teoria do poder limitado. No constitucionalismo, o poder constituinte é cerceado pelas leis que ele próprio instituiu. Assim, diante dessa aparente impossibilidade de se pensar o poder constituinte como um conceito absoluto, Negri vai afirmar:

\begin{abstract}
"O paradigma do poder constituinte, ao contrário, é aquele de uma força que irrompe, quebra, interrompe, desfaz todo equilíbrio preexistente e toda continuidade possível. O poder constituinte está ligado à ideia de democracia concebida como poder absoluto. Portanto, o conceito de poder constituinte, compreendido como força que irrompe e se faz expansiva, é um conceito ligado à pré-constituição da totalidade democrática. Pré-formadora e imaginária, esta dimensão entraem choque com o constitucionalismo de maneira direta, forte $\mathrm{e}$ duradoura. Neste caso, nem a história alivia as contradições do presente: ao contrário, esta luta mortal entre a democracia e constitucionalismo, entre o poder constituinte e as teorias e práticas dos limites da democracia, torna-se cada vez mais presente na medida em que a história amadurece o seu curso." ${ }^{\text {"6 }}$
\end{abstract}

O problema, portanto, parece estar na sua constitucionalização. É preciso pensar em um modelo constitucional que não o limite, que seja um espaço de proliferação de sua força dinâmica.Assim, o que se deve questionar é quem seria o sujeito desse poder constituinte. Observe-se que, como foi referido anteriormente, para a tradição da ciência jurídica, o sujeito desse poder é a vontade comum, sendo esta a soma de todas as vontades individuais. Ora, nesse contexto, não seria possível pensar um poder constituinte expansivo, já que essa vontade comum já constitui a totalidade de todos os desejos. O poder constituinte seria, assim, uma força

\footnotetext{
${ }^{68}$ Ibid., p. 21
} 
“imutável”, mero fundador das normas jurídicas fundamentais. Se o poder constituinte é sempre o mesmo, não haveria problema em se supor que as normas que foram instituídas por ele em um dado momento corresponderiam sempre àquela vontade inicial.

Porém, o que Negri está propondo aqui é pensarmos em um poder constituinte mutável, expansivo. E para que isso seja possível, é preciso considerar o sujeito do poder constituinte como a multidão, que, como foi discutido no segundo capítulo, é mais do que a mera soma das vontades individuais. Conforme anteriormente exposto, a multidão é formada pelos indivíduos que a compõem, que são como partículas, ligados por uma relação de movimento e repouso. Desse conceito devemos entender que a multidão é dinâmica e que ela tem uma potência de auto conservação, já que ela persevera para manter estável as relações entre suas partes. Mais do que isso: a multidão é uma multiplicidade, ela não se caracteriza pelo achatamento e identificação dos indivíduos, mas por suas diferenças ${ }^{69}$.

\begin{abstract}
"De um ponto de vista sociológico e de filosofia da sociedade, falamos antes de mais nada em multidão como conjunto, como uma multiplicidade de subjetividades, ou melhor, de singularidades; em segundo lugar, falamos em multidão como classe social não-operária (...); enfim, em terceiro lugar, quando falamos em multidão nos referimos a uma multiplicidade não esmagada na massa, mas capaz de desenvolvimento autônomo, independente, intelectual (...).
\end{abstract}

\footnotetext{
${ }^{69} \mathrm{O}$ autor irá se estender sobre o conceito de multidão, em conjunto com Michael Hardt, em sua obra "Multidão - Guerra e Democracia na era do Império". Sobre o tema, pode-se destacar a seguinte passagem: "Vimos que a carne da multidão produz em comum uma maneira que é monstruosa e sempre ultrapassa a medida de quaisquer corpos sociais tradicionais, mas essa carne produtiva não cria caos e desordem, $\mathrm{O}$ que ela produz, na realidade, é comum, e o comum que compartilhamos serve de base para a produção futura, numa relação expansiva em espiral. Isto talvez possa ser mais facilmente entendido em termos do exemplo da comunicação como produção: só podemos nos comunicar com base em linguagens, símbolos, ideias e relações que compartilhamos, e por sua vez os resultados de nossa comunicação constituem novas imagens, símbolos, ideias e relações comuns. Hoje essa relação dual entre a produção e o comum - o comum é produzido e também é produtivo - é a chave para entender toda atividade social e econômica." (HARDT, Michael e NEGRI, Antonio. Multidão - Guerra e democracia na era do Império; traduzido por Clóvis Marques. Rio de Janeiro: Record. 2005. p. 256, 257)
} 
A multidão, definida assim, apresenta-se como conceito aberto, dinâmico, constitutivo."

Assim, pode-se começar a compreender o porquê de o poder constituinte resistir à constitucionalização. É por isso que Negri o caracteriza como "conceito de uma crise": porque, dentro da tradição constitucionalista tal como nos é apresentada, definir o poder constituinte é limitá-lo. E essa é, assim, a grande pergunta que o autor buscará responder: como pensar em um poder constituinte verdadeiramente ilimitado? Em uma democracia absoluta? Será que é possível conceber instituições políticas que não aprisionem seu caráter dinâmico?

Para tanto, a metodologia utilizada é uma análise de fatos históricos que ajudaram a moldar os alicerces da atual ciência jurídica e que foram fundamentais no desenvolvimento do conceito de poder constituinte. São eles: a Renascença, a Revolução Inglesa, a Revolução Americana, a Revolução Francesa e a Revolução Russa. Para cada um desses eventos, ele se apoiará na visão de um filósofo que teve um papel relevante na interpretação destes, quais sejam, respectivamente: Maquiavel, Harrington, Jefferson, Rousseau e Marx. O seu objetivo, mais do que uma mera revisitação a esses períodos, é propor um novo entendimento sobre o significado de cada um deles e de como se deu neles a manifestação do poder constituinte. $\mathrm{Ou}$, nas palavras do próprio autor:

\footnotetext{
“Ao acompanhar, do ponto de vista histórico, a formação do conceito de poder constituinte, nossa pesquisa não seguirá uma trajetória contínua, mas deverá verificar hipóteses distintas. Assim, em cada um dos cinco capítulos que se seguem a este, dedicado a apresentação do problema, nós analisaremos uma figura particular de formação do conceito de poder constituinte e o seu destino singular., 71
}

\footnotetext{
${ }^{70}$ NEGRI. Antonio. Cinco Lições sobre Império. Traduzido por Alba Olmi. Rio de Janeio: DP\&A, 2003. pp. 145,146

${ }^{71}$ NEGRI, Antonio. O Poder Constituinte - ensaio sobre as alternativas da modernidade; tradução de Adriano Pilatti - Rio de Janeiro: Ed. 1, DP\&A, 2002. p. 55
} 
De forma didática, pode-se dizer que Negri apresenta em cada um desses capítulos um "instrumento" para a busca de um caminho para o poder constituinte. Em Maquiavel, ele destaca a ideia do "povo em armas", o que pode ser interpretado como um povo que tenha forças para se opor e resistir ao soberano; em Harrington, ele discorre sobre o contrapoder, ou antipoder; na Revolução Americana, ele aponta a expansão das fronteiras geográficas como expressão da potência constituinte; na Revolução Francesa, a preocupação não é mais comuma expansão geográfica, mas em se pensar o poder constituinte no tempo, na necessidade de se superar a "temporalidade burguesa"; por fim, com Marx, ele irá pensar o trabalho vivo como forma de libertação do povo.

Assim, o que o autor busca nesses eventos e nesses autores serão elementos capazes de embasar essa nova formulação do conceito de poder constituinte, uma definição que não o limite, uma (des)institucionalização que não o imobilize.

\subsection{O Conceito de uma Crise}

No último capítulo do "Poder Constituinte", Negri aponta três dimensões ideológicas do pensamento ocidental que se apresentam como limites para a concretização do projeto político que ele propõe.

Primeiramente, Negri menciona a "tradição judaico cristã da criação" ${ }^{, 72}$. Por tudo que já foi aqui exposto, está claro que a ideia de um ser transcendente responsável pela criação do mundo vai radicalmente de encontro ao que está sendo proposto. Pensar em um Deus criador é uma forma de imobilizar e neutralizar a potência da multidão. Mas, mais do que isso, Negri também discorda dos pensamentos ateístas de Maquiavel, Espinosa e Hobbes. Enquanto ele irá considerar o fato desses autores reconduzirem o momento da criação para o homem como um rompimento

\footnotetext{
${ }^{72}$ Ibid.. p. 426
} 
com a tradição e um grande avanço no estabelecimento de um poder constituinte entendido como afirmação de uma potência, ele irá criticar o fato de que todos eles reconduzem, em algum momento, o conceito da criação a uma experiência unitária ${ }^{73}$.

Para o autor, será fundamental pensar a criação como um movimento da multidão e das diferentes partes que a compõem. Afinal, como já foi apontado, a multidão se caracteriza pela multiplicidade, pelas diferenças de suas partes e não pelas suas similaridades. Assim, apenas pensando em uma multiplicidade de experiências criadoras, poderemos pensar em uma imaginação constituinte que se mantenha sempre em um movimento de transformação e expansão.

"Lá aonde existe a possibilidade de configuração unitária de todos os atos criadores da potência, a criação não se libera da divindade: assistiremos sempre ao retorno triunfante daquela categoria de totalidade que se une $\grave{A}$ de unidade para promover a redução das diferenças, a absorção das multiplicidades singulares e a homogeneização destas. Ao contrário, é na relação essencial entre criação e multiplicidade que reside a especificidade do projeto constituinte, a definição daquilo que lhe é próprio. Nisto consiste a sua crise, que é própria de seu conceito, na medida em que não se refere apenas ao bloqueio da progressão temporal da criatividade, mas sobretudo - e em termos bem mais qualitativos - à multidão de alternativas criadoras." ${ }^{74}$

O segundo limite imposto pelo poder ocidental, segundo Negri, seria a perspectiva jusnaturalista. Para ele, o perigo das concepções jusnaturalistas é que elas estão tão intrinsecamente ligadas à modernidade e pode se mostrar mais difícil do que parece se libertar de suas amarras: mesmos aqueles autores que se opõem a essa linha de pensamento, em algum momento acabam por fazer alusão a uma série de direitos abstratos ou algo do gênero, ainda que não aceitem o jusnaturalismo como um

\footnotetext{
${ }^{73}$ Ao se referir ao pensamento desses três filósofos, Negri afirma : "Contudo, esta formidável mélangede elementos críticos e construtivos não consegue eliminar definitivamente aquele momento em que, na tradição judaico-cristã, toda experiência é reconduzida à unidade. Expropriar Deus de sua força criadora não será decisivo se nela conservamos a dimensão unitária do projeto criador. Assim fazendo, mundanizamos a divindade sem suprimi-la - e o poder constituinte deverá continuar a confrontar-se com a universalidade do projeto" (Ibid., p. 427)

${ }^{74}$ Ibid., p. 428
} 
sistema. Assim, enquanto a tradição judaico-cristã limita o poder constituinte ao pensá-lo de forma unitária, o jusnaturalismo irá limitá-lo ao pensá-lo de forma preconcebida.

\footnotetext{
"Mesmo em Marx, ferrenho adversário de todo 'catálogo pomposo dos direitos do homem', um certo humanismo abstrato, configurado no resíduo ideológico do 'comunismo primitivo', deixa-se entrever. Com certeza, isto pouco tem a ver com o jusnaturalismo, concebido como sistema de pensamento e função disciplinar, mas é de todo modo relevante, pois revela uma influência perversa, um duro limite oposto à criatividade incondicional do trabalho constituinte. Se a tradição judaico-cristã tenta bloquear a potência instalando-a numa perspectiva unitária, a tradição jusnaturalistas procura encerrar a potência num esquema preconcebido. No primeiro caso, ataca-se sobretudo a multidão; no segundo, é a vez da potência: em ambos os, ocorre o bloqueio da relação aberta multidão-potência. Mas é nesta relação aberta que estão o conceito e a prática do poder constituinte."75
}

Por fim, o terceiro limite imposto pelo pensamento ocidental seria o transcendentalismo. Nesse caso, Negri afirma que esse pensamento pode se traduzir tanto em um idealismo quanto em um formalismo. No idealismo absoluto o que ocorre é que as condições de exercício do poder constituinte são consideradas como as mesmas da própria realidade. Dessa forma, o poder constituinte ao invés de ser considerado como um movimento de ruptura, fica diluído no que Negri vai chamar de "indiferença do real". Ou seja: o idealismo pensa o poder constituinte como o próprio processo de transformação da realidade como um todo e, ao fazê-lo, elimina a potência inovadora do poder constituinte.

Por outro lado, pode-se conceber o transcendentalismo pelo viés formalista de Kant. Nesse caso, o grande problema seria o de que, apesar de Kant reconhecer a existência da potência e da multidão, ele irá reduzir o princípio constituinte ao individualismo. Para ele, a revolução é um objeto do pensamento do indivíduo, uma construção ética dotada de significado pelo próprio indivíduo. Ao fazer esta redução, Kant afasta a potência da multidão e a relega apenas ao indivíduo, acabando assim por negar o poder constituinte ao colocar a ética acima da política.

\footnotetext{
${ }^{75}$ Ibid., p. 429
} 


\begin{abstract}
"No entanto, poder-se-ia objetar, esse individualismo formal está aberto, nada o impede de se desenvolver no processo da imaginação, de se ligar à revolução como a uma função esquemática da razão! Sob este ponto de vista, poder-se-ia acrescentar, as duas correntes que historicamente definiram o poder constituinte poderiam ser reunificadas no formalismo kantiano, e os indivíduos poderiam se transformar em coletividade, a liberdade individual fazer-se democracia. Não é assim: a operação crítica, longe de operar uma mediação progressiva, destrói o nexo problemático entre potência e multidão, dando-lhe a forma definitiva da supremacia da ética sobre a política e isola o poder constituinte no vazio da intencionalidade individual., ${ }^{, 76}$
\end{abstract}

A partir dessas observações, Negri chega a três conclusões: primeiramente, a de que esses limites só são relevantes na medida em que se pensa no poder constituinte como poder constituído, tornando-se ineficazes se passarmos a conceber o poder constituinte como expressão da potência que o constituiu; em segundo lugar, a de que ao pensarmos no poder constituinte como potência, estamos nos referindo àquela imaginação constituinte ou, como Negri irá chamar, um "paradigma de uma dimensão temporal aberta para o futuro",77.

Por fim, o autor afirma que esses limites só são eficazes porque o poder constituinte nunca conseguiu se libertar das amarras da modernidade. Segundo ele, o grande problema da racionalidade moderna é a incapacidade de conceber o limite do poder constituinte como absoluto, tendo sempre que tentar finalizar o processo pelo poder constituído, dentro das noções tradicionais de soberania. Esse é o desafio que nos é apresentado, como conceber esse poder constituinte que extrapola os limites da modernidade, que não se deixe ser neutralizado, esvaziado.

\footnotetext{
"Este impulso contínuo rumo à superação dos limites do racionalismo leva o poder constituinte do liberalismo à democracia e ao socialismo, mas ele se perde sempre, pela impossibilidade de aceitar o limite como absoluto. O Estado, o poder constituído, a concepção tradicional de soberania sempre reaparecem para concluir com o processo constitutivo. Assim, o nosso problema passa a ser o de compreender como essa jornada de contradições chega a seu fim, como esse destino é sempre esvaziado de toda eficácia. (...) É preciso analisar o modo pelo qual o poder constituinte, após ter funcionado como motor do desenvolvimento
}

\footnotetext{
${ }^{76}$ Ibid., p. 431

${ }^{77}$ Ibid., p. 431
} 
do racionalismo ocidental, pode agora dobrar-se sobre sua própria força singular, para exprimi-la completamente, na plenitude de sua intensidade." 78

Negri vai dividir em dois grupos os eventos históricos por ele analisados: no primeiro, no qual ele coloca a Revolução Inglesa e a Revolução Americana, ele diz que o aprisionamento do poder constituinte pela lógica da modernidade se dá por uma limitação espacial. O que ocorre é que nesse caso o poder constituinte é confinado ao espaço da "política", que é separado do social e, assim, passa a ser definido pelas instituições constituídas. Nesse sentido, todas as formas de organização social são afastada da política e por ela dominadas através do processo da "representação" e o próprio poder constituinte passa a significar apenas a ação desses mecanismos representativos. A neutralização do poder constituinte se dá, portanto, na medida em que retiram dele sua potência inovadora, fazendo com que este apenas possa se manifestar apenas das estruturas preconcebidas do constitucionalismo.

No segundo grupo, o problema não vai estar mais associado à racionalização do espaço, mas à racionalização do tempo. Usando como exemplo a Revolução Francesa e a Revolução Russa, Negri vai afirmar que o aprisionamento do poder constituinte no espaço político não é mais o caso para esses eventos, na medida em que eles concebem o poder constituinte como fruto do trabalho vivo dos indivíduos ou, em outras palavras, como forma da potência produtiva da sociedade.

Por outro lado, o poder constituinte é submetido à racionalidade da modernidade em seu aspecto temporal. O poder constituinte passa a ser concebido como dialética do tempo e, nesse sentido, passa a ser apenas mais um aspecto de sua constitucionalização. O que ocorre, portanto, é que passa-se a se pensar na dinâmica temporal como uma série de intervalos constitucionalizados que se sucedem um aos outros: a força de renovação do poder constituinte passa a estar submetida a essa dialética preconcebida da dinâmica temporal.

\footnotetext{
${ }^{78}$ Ibid., p. 432
} 
"Se considerarmos agora o segundo grupo de experiências constituintes e sistemas constitucionais que estivemos analisando, concernentes Às Revoluções Francesa e Russa, a resposta a um questionamento análogo não só não permite resolver o primeiro problema como torna-o ainda mais complicado. Se, no primeiro caso, o poder constituinte estava preso ao poder constituído como a um esquema de organização raciona o espaço, neste segundo grupo a racionalização passa por um projeto de organização do tempo. Certo, a inovação aa que assistimos aqui é imensa - não é o lugar, mas a atividade dos homens que se toma em consideração; não a generalização abstrata dos cidadãos, mas a concretude do trabalho; não o poder constituinte numa estreita configuração política, mas o poder constituinte como forma da força produtiva da sociedade." ${ }^{39}$

Mas então volta-se a pergunta: como libertar o poder constituinte da racionalidade da modernidade? A resposta de Negri vai ser a de pensá-lo como conceito de uma crise. E essa crise consiste exatamente na interrupção da potência constituinte pelas instituições do poder constituído. Mas essa crise não deve ser vista como um limite, mas sim como um obstáculo a ser superado pela potência da multidão. Nesse sentido, Negri vai traçar o caminho que deve ser seguido para que seja exercido o poder constituinte: "Assim, as condições de realização do poder constituinte são postas como espaço reconduzido ao tempo, como tempo reconduzido à potência, como potência reconduzida ao sujeito." 80

E faz sentido pensar o poder constituinte como conceito de uma crise na medida em que ele é uma fundação, uma criação. $O$ poder constituinte deve, portanto, ter início quando há o rompimento radical com a lógica da modernidade. Ele deve ser uma forma política completamente nova, que não deve se basear em nada exterior à potência da multidão. Nesse sentido, também, a própria relação entre potência e multidão deve acrescentar a esse entendimento, na medida em que ela deve ser entendida como uma relação aberta, que está sempre em construção e em transformação. Assim, mais uma vez, chegamos ao conceito da democracia, tal como apresentado anteriormente, como a única resposta possível, como o único sistema

\footnotetext{
${ }^{79}$ Ibid., p. 435

${ }^{80}$ Ibid., p. 440
} 
político aceitável para a realização desse poder constituinte entendido como conceito de uma crise:

\begin{abstract}
"Entenda-se: aqui, democracia significa expressão integral da multidão, radical imanência da potência, exclusão de toda definição externa - seja ela transcendente ou transcendental - a este radical e absoluto campo de imanência. Esta democracia é o oposto do constitucionalismo, ou melhor, a negação do constitucionalismo como poder constituído que se torna impermeável Às modalidades singulares do espaço e do tempo, como máquina menos predisposta ao exercício da potência do que ao controle de suas dinâmicas e à fixação de relações de força imutáveis. O constitucionalismo é transcendência, mas é sobretudo o policiamento que a transcendência exercita sobre a totalidade dos corpos para impor-lhes a ordem e a hierarquia. O constitucionalismo é um aparato que nega o poder constituinte e a democracia." ${ }^{\prime 1}$
\end{abstract}

A racionalidade da modernidade, por sua vez, se esforça sempre por negar essa potência. A tradição política teme a força da multidão, a criação dessa subjetividade que escapa a sua lógica. Dessa forma, a filosofia política moderna age na tentativa de definir o poder constituinte como extraordinário, transcendente ou de limitá-lo, encerrá-lo em um poder constituído.

A solução, então, será conceber o poder constituinte como uma realidade social. Ele é concretizado através da produção do trabalho vivo. Assim, o sujeito desse poder constituinte deve ser pensado como uma força produtiva, que está sempre remodelando o mundo à medida que o vai construindo. Perde-se toda a noção de finalismo, de dialética, de predeterminação. Mas, assim, se esse conceito nega a racionalidade moderna, como deve ser concebida a nova racionalidade que ele integra? Negri destaca cinco pontos em que essas duas concepções de mundo se opõem.

Inicialmente, a nova racionalidade se difere da racionalidade moderna pelo seu caráter ilimitado. O limite apenas existe para ser superado, como condição de sua expansão e, portanto, de sua existência. Mesmo o conceito de medida é esvaziado de seu significado: as medidas serão construídas a medida que forem sendo construídos os objetos a serem

\footnotetext{
${ }^{81}$ Ibid., p.444
} 
medidos. Negri afirma que o poder constituinte é uma desmedida ou uma medida progressiva, pois estes (medidas e limites) só podem ser considerados como elementos dinâmicos do poder constituinte.

A segunda oposição destacada por Negri é, segundo ele, a do "procedimento-processo contra o mecanismo de dedução do direito subjetivo e da máquina constitucional" 82 . Em outras palavras, o que está sendo proposto aqui é que o direito pare de ser pensado através de normas gerais e abstratas, que deixem de existir regras de procedimento fixadas e imutáveis: o que deve ser levado em consideração são as relações que estão sendo formadas e o constante movimento de expansão e modificação da sociedade. Nesse contexto, as normas, quando existirem, devem ser permanentemente reavaliadas. O procedimento deve ser entendido como forma de expressão da subjetividade. Mas é importante destacar que esse pensamento não deve ser confinado ao campo jurídico, mas utilizado em todos os aspectos dessa nova sociedade.

Em terceiro lugar, está a oposição da igualdade contra o privilégio. E é importante ressaltar que a igualdade não é entendida aqui como direito fundamental ou como um objetivo a ser alcançado. Ela é, na verdade, uma condição para o exercício do poder constituinte. Nessa nova racionalidade não existem medidas e limites, as instituições não são rígidas, mas dinâmicas. Assim, a própria noção de privilégio é inconcebível, incongruente. Por outro lado, a relação entre multidão e potência só pode ser concebida através da igualdade das partes que a formam, igualdade material, de modo que possa haver um fluxo ilimitado, sem bloqueios, dessas partes.

A quarta oposição se relaciona intrinsecamente à terceira e diz respeito à diversidade como resposta à uniformidade. Sobre esse tópico, bastante já foi falado. Em suma, a multidão não pode ser entendida como uma massa unificada, ela não se configura pela semelhança entre suas partes, mas por suas diferenças. A multidão deve ser entendida, antes de 
tudo, como uma multiplicidade. Além disso, nesse processo dinâmico e expansivo de constante reconstrução do que se está construindo, não é possível conceber um mundo uniformizado: a uniformidade é rompida no mesmo momento em que é constituída.

Por fim, a última oposição é a da cooperação contra o comando. A cooperação é a articulação entre as singularidades da multidão. A cooperação é a base da política, da democracia. É a partir dela que toda a produção constituinte irá ocorrer. O comando, por sua vez, é o fim dessa produção, é a uniformidade, a fixação do poder constituinte. Assim, a nova racionalidade só pode ser pensada segundo a cooperação, pois só nesse registro podemos pensar no movimento de produção da imaginação constituinte, um poder constituinte que se expressa através de uma construção e reconstrução permanente do real.

Com isso, Negri conclui seus pensamentos sobre a racionalidade pós moderna, resumindo da seguinte maneira a sua concepção de política tal qual foi apresentada:

"Constituição dinâmica, criadora, contínua e processual da potência: a política é isso. Esta definição não é vazia ou neutra: está sujeita a determinações da subjetividade e da tendência, ou seja, às figuras nas quais multidão e potência se reencontram como figuras da cooperação produtiva. Mas a expressão da multidão e a criação contínua de um novo modo de vida permanecem como elementos fundamentais. Privar a política de tais elementos é tomar-lhe tudo, é reduzi-la a pura mediação administrativa e diplomática, a atividade burocrática e de polícia, ou seja, é reduzi-la exatamente àquilo contra que o poder constituinte, como origem da política, luta sem cessar, para emergir como potência." ${ }^{" 83}$

\subsection{O Antipoder}

Como pode ser observado pelo trecho citado acima, Negri e Rancière, em mais momentos do que não, apresentam concepções muito similares sobre a política e o poder constituinte. Mas cabe destacar uma diferença fundamental entre esses conceitos tais como concebidos pelos

\footnotetext{
${ }^{83}$ Ibid., p. 460
} 
dois autores, diferença esta que será fundamental para que se entenda esse conceito.

Como pode-se observar no capítulo anterior, o conceito de política para Rancière é, antes de mais nada, um conceito extraordinário. A política ocorre em um momento determinado do tempo e do espaço (como foi visto, a política é sempre local e temporária), dependendo de uma conjugação específica de fatores que permite o desenvolvimento de um conflito acarretado por um dano que consiste na afirmação de uma parcela da sociedade.

Para Negri, porém, é um erro pensar a política como um evento fundamentalmente extraordinário. Como foi dito acima, a grande preocupação do autor é conceber um poder constituinte absoluto. Assim, não faz sentido se conceber um conceito que seja, por definição, limitado temporal e espacialmente.

Assim, ainda que em muitos momentos as teses desses dois autores possam parecer similares e complementares, nisso elas se mostram intrinsecamente opostas. Os dois irão pensar em um poder constituinte da multidão, imanente e radical, no sentido em que ele rompe com a ordem vigente de forma estrutural. Porém, enquanto para um deles esse movimento se dá apenas em um determinado intervalo de tempo para depois se encerrar, para o outro ele só pode ser pensado como um conceito constantemente dinâmico e produtivo.

Mas como Negri pode escapar do paradoxo apontado por Rancière? Do fato de que o princípio da igualdade, fundamental para a ocorrência da política, não lhe é próprio? É nesse momento que se faz relevante o princípio do antipoder.

Esse conceito é caracterizado por uma trindade: resistência, insurreição e poder constituinte. A resistência é aquela forma de enfrentamento mais banal, que pode ser experimentada por qualquer um em seu cotidiano; já a insurreição, por sua vez, é uma resistência de massa 
organizada. O poder constituinte é a forma de expressão da inovação trazida pelos movimentos anteriores, é uma potência transformadora:

"O poder constituinte é a potência de configurar a inovação que resistência e insurreição produziram, e de dar-lhe uma forma histórica adequada, nova, teleologicamente eficaz. Se a insurreição obriga a resistência a se tornar inovação (e expressa, portanto, a produtividade que irrompe do trabalho vivo), o poder constituinte dá forma a essa expressão (acumulada a potência de massa do trabalho vivo em um novo projeto de vida, em um novo potencial de civilização). $\mathrm{E}$, se a insurreição é uma arma que destrói as formas de vida do inimigo, o poder constituinte é a força que organiza positivamente novos esquemas de vida e de gozo de massa da vida." ${ }^{\prime \prime}$

Assim, em um primeiro momento não parece haver nenhuma mudança radical entre esse conceito e o conceito de política tal como proposto por Rancière: os dois são pensados como uma ruptura com a ordem vigente, que depende de um movimento de integração da parte oprimida da sociedade, com o fim de constituir uma nova ordem. Mas é nesse último momento que se encontra a diferença: para Rancière, em um dado momento, as forças que estão em conflito chegarão a uma conclusão, a uma nova partilha do sensível, e com o encerramento do conflito, se dá também o encerramento da política, que só voltará a se manifestar quando houver um novo questionamento sobre a então atual partilha.

Negri, porém, ao afirmar que o poder constituinte deve ser a expressão da potência inovadora não está apenas se referindo ao poder constituinte como o instrumento de concretização dos anseios daquela insurreição. O poder constituinte deve ser "um processo irreversível de transformação dos modos de vida e de afirmação de desejos de libertação." ${ }^{85}$. Ou seja: não basta que o antipoder desestruture o poder vigente; é preciso também que ele não substitua o poder que foi derrubado, mas que em seu lugar seja posta uma força dinâmica, transformadora, uma imaginação constituinte.

\footnotetext{
${ }^{84}$ NEGRI. Antonio. Cinco Lições sobre Império. Traduzido por Alba Olmi. Rio de Janeio: DP\&A, 2003. p. 198

${ }^{85}$ Ibid., p. 199
} 
"O antipoder, para ser exercido e ser eficaz, deve, portanto, ser duplo: por um lado escavar, desmantelar continuamente, minar a estrutura social do poder; por outro, intervir de modo ofensivo sobre/contra as operações de estabilização que o poder continua repetindo e que constituem o específico de sua capacidade de governo. Ao 'antipoder' que desestrutura deve corresponder também um 'antigoverno' que desestabiliza. Em terceiro lugar, há a ação do poder constituinte. Ela é a que amplia - sobre todo o território do poder e de encontro a ele - a imaginação alternativa: é pensar, todos juntos, o porvir como potência da multidão, como uma nova forma de produção e de reprodução da vida, e de luta contra a morte." ${ }^{, 86}$

O problema do antipoder seria, em outras palavras, a constitucionalização. A resistência tem o objetivo de desestruturar o poder constituído através de um jogo de micropoderes, ir aos poucos atacando e esvaziando as instituições vigentes; a insurreição é a força explosiva que tem como finalidade impedir uma reação e uma reestruturação do sistema. E, por fim, há o poder constituinte, como acima descrito. O problema está no que Negri chama de reterritorialização: a tentativa do poder constituído de limitar no espaço e eventualmente neutralizar o antipoder. Essa tentativa se dá, normalmente, no momento de transição entre a insurreição e a instauração do poder constituinte. E a estratégia para essa recuperação é o constitucionalismo, pois ele reduz essa potência constituinte a meras pretensões jurídicas. Dessa forma, impede-se a reestruturação do sistema: algumas demandas são supridas, outras não, mas o questionamento inicial sobre as estruturas de poder nunca é reconhecido.

Negri cita Espinosa nesse ponto. Ele irá mencionar a teoria do filósofo sobre a democracia absoluta. Como foi abordado no segundo capítulo, para Espinosa a democracia é a forma mais natural de governo. Resumidamente, ele chega a essa conclusão partindo da premissa de que todos querem governar e não querem ser governados e de que a multidão é um corpo formado pela relação entre as diversas partes que a constituí e tanto mais forte ela será quanto mais forte forem essas partes. Sendo assim, a potência da multidão chega a seu ápice quando todas as suas partes estiverem governando e não sendo governadas. Porém, o que é importante

\footnotetext{
${ }^{86}$ Ibid., p. 201
} 
de destacar desse conceito, é que a democracia absoluta, tal qual descrita por Espinosa, não é a mesma democracia da teoria clássica das formas de governo: monarquia, aristocracia e democracia.

\begin{abstract}
"Mas, ao lado dessa democracia, acrescenta 'absoluta' - e isso resulta em 'democracia absoluta', isto é, uma forma de governo que não tem mais relação com as demais formas de governo, porque a multidão, quando comando para si mesma supera todas as outras formas de existência social organizada, não se apresenta como teoria política de uma determinação, mas do ser sem determinações, absoluta em toda parte e sem limites. Portanto, é perfeitamente possível pensar em uma forma de poder que não tem relação com o poder monárquico ou com o poder aristocrático - e também nenhuma relação com o poder democrático quando este seja ainda uma das figuras do poder mais do que função da potência da multidão." ${ }^{87}$
\end{abstract}

Ou seja: a democracia absoluta não se enquadra no trinômio "governo de um, governo de poucos e governo de muitos" porque a própria palavra "governo" aqui assume um significado diferente, resultando que a democracia absoluta só pode ser pensada como o governo de todos, o governo da multidão. Não é possível pensar nela como uma alternativa ao "governo de um" ou ao "governo de poucos" pois estes são fundamentalmente diferentes, são governos que deverão ser exercidos por um poder constituído, limitado, imobilizado. A democracia absoluta só pode ser pensada como um governo do poder constituinte: dinâmico e sempre expansivo. Esse é, portanto, o único governo aceitável para o antipoder: se este tiver como resultado qualquer outra foram de governo que não a democracia absoluta, então pode-se dizer que o poder constituído foi bem sucedido em sua tentativa de reterritorialização.

Negri ressalta que essa neutralização ocorre sempre que a resistência atuar em um vazio. $\mathrm{O}$ que ele quer dizer com isso é que a resistência tem que ser proporcional a potência da multidão que a está exercendo, ou seja, não basta que existam forças para destruir o poder constituído: é preciso que haja força na imaginação constituinte. A resistência e a insurreição são ineficazes se não estiverem conectadas a um poder constituinte que permita

${ }^{87}$ Ibid., p. 202 
que o processo de transformação por elas proposto continue atuando ilimitadamente. Nesse ponto, o autor irá apontar também o perigo de se pensar o antipoder em uma perspectiva de "imediatidade", ou seja, de se pensar seus três tempos (resistência, insurreição e poder constituinte) como uma sucessão de movimentos espontâneos e indiferenciados. Ele diz que as consequências dessa forma de ação são sempre desastrosas porque impedem um pensamento crítico sobre o próprio movimento, o que é fundamental para que ele não se torne apenas um ato de paixão irrefletido. Em outras palavras, para Negri é essencial que a experiência do antipoder vivencie de forma completa todas as suas etapas, para garantir a expansão máxima de sua potência.

\begin{abstract}
"Assim, de fato, a resistência, tomada em si mesma, em sociedades altamente complexas como as pós-modernas, pode atuar no vazio ou, pior, ser manipulada em operações de circulação sistêmica que somente a recomposição de um ponto de vista global de antipoder pode interromper. Assim, a tensão insurrecional, por mais generosa que possa ser, pode tornar-se inútil, ou até danosa, se não for adequada ou proporcional às potencialidades de massa; ela corre o risco de naufragar nos lodaçais do terrorismo, quando sua incidência não se tenha tornado de massa (através de fases anteriores de resistência) e sua imaginação constituinte não se tenha tornado hegemônica." 88
\end{abstract}

Por fim, Negri, assim como Rancière, tenta pensar o antipoder (ou a política, na terminologia do segundo) no plano internacional, levando em consideração as circunstâncias específicas de um mundo globalizado. Ipara Negri, é possível pensar em um antipoder em uma sociedade globalizada. Segundo ele, o próprio conceito de nação é um obstáculo ao antipoder, no sentido em que pensar em um antipoder confinado às fronteiras geográficas impostas pelo poder constituído é uma forma de limitá-lo. Assim, em uma primeira vista, parece que a globalização, antes de ser um problema, é uma solução.

Contudo, a preocupação de Negri é que a globalização apenas expandiu a lógica do poder constituído para níveis internacionais: assim, agora mesmo quando o poder constituinte consegue escapar ao limite das

\footnotetext{
${ }^{88}$ Ibid., p. 199
} 
fronteiras nacionais, ele ainda corre o risco de ser aprisionado pelo que o autor irá chamar de um “constitucionalismo imperial”.

Negri acredita ser possível que o antipoder supere esse constitucionalismo imperial. A maneira de fazê-lo seria análoga ao plano nacional: é preciso conceber um movimento de resistência e insurreição que sejam apoiados por uma potência forte o suficiente para que possa chegar ao poder como força transformadora, ilimitada. Assim, sem dar uma resposta definitiva, Negri irá propor que seja feita uma reflexão sobre as experiências anteriores em busca de se encontrar o caminho para um antipoder atual:

\footnotetext{
"A primeira experiência (válida, desde sempre) é a de construir resistência a partir de baixo, por meio de um enraizamento das situações sociais e produtivas. Trata-se, pois, de continuar, mediante uma militância resistente, a desestruturar o poder dominante nos lugares em que se acumula, se centraliza e de onde declara sua hegemonia. Resistir de baixo significa alargar na resistência as redes do saber e do agir 'comuns', contra a privatização do comando e da riqueza. Significa romper as linhas duras da exploração e da exclusão. Significa construir linguagens comuns, nas quais a alternativa de uma vida livre e de luta contra a morte se mostre vencedora. (...) Mas, para se tornarem estratégias, essas lutas precisam encontrar uma coligação mundial, uma dimensão de circulação global. Precisam ser sustentadas por potências materiais, no caso, por uma força-trabalho que se movimenta através de linhas de emigração cultural e laboral, materiais e imateriais, de um êxodo cosmopolítico poderoso e radical." 89
}

${ }^{89}$ Ibid., pp. 207, 208 


\section{CONCLUSÃO}

Como anunciado, esse trabalho teve o objetivo de desafiar a noção tradicionalmente aceita acerca do tema do poder constituinte. Tal como é pensado, através de uma perspectiva transcendente e limitada, esse conceito perde a sua radicalidade e pode passar a ter implicações profundamente antidemocráticas, na medida em que opera uma separação entre político e social, que impede que as transformações deste sejam acompanhados por aquele.

Propondo uma nova concepção para esse conceito, iniciamos por uma análise da obra "O Desentendimento", de Rancière. Com essa análise, identificamos a concepção de política para o autor e as condições para o exercício da mesma: o princípio da igualdade, o dano, o conflito.

Assim, vimos que para o autor a política é iminentemente democrática, ela é um momento de reinvindicação e luta da "parcela dos sem parcela" por uma nova partilha do sensível. Esse movimento, contudo, só pode ocorrer após a subjetivação dessa classe, no momento em que ela se reconhece como tal.

Também deve ser destacado que Rancière ressalta que a política é sempre temporária e local. Isso ocorre porque a igualdade, que é condição para o exercício da política, também é estranha a ela. Nesse sentido, o autor afirma que a política é sempre excepcional e que ela pode ocorrer em qualquer contexto, desde que estejam presentes as condições acima mencionadas.

Por fim, o autor ressalta os mecanismos utilizados pela filosofia política para afastar a política do social: a arqui-política e a sua perfeita divisão de espaços e a para-política, que inscreve o conflito dentro da ordem constitucional. A meta-política, por sua vez, tal como proposta por Marx, apenas reconhece a diferença entre 
a política e a mentira constitutiva desta, ou seja, o fato da igualdade, que é princípio constitutivo da política, estar tão distante dela.

Rancière conclui fazendo uma análise das sociedades pós-modernas, as quais ele afirma se encontram na democracia consensual. Para ele isso seria, em suma, o fim da política. Democracia e consenso são palavras opostas, pois a democracia pressupõe o conflito pela partilha do sensível, em outras palavras, a democracia depende do dissenso. A democracia consensual, ou pós democracia, seria o momento posterior ao conflito. Nesse momento, o litígio político é transformado em uma questão judicial e o Estado passa a ser o gestor do conflito.

Assim, através da tese de Rancière, o que se pretendeu demonstrar é que a política deve ser entendida sempre como um momento constitutivo de uma nova ordem e que esse momento deve ser sempre democrático, deve ser a reinvindicação de uma parcela do corpo social que não se encontra satisfeita com o estado das coisas e pode finalmente se identificar como uma classe capaz de iniciar um conflito, uma luta.

Por outro lado, o autor tangencia durante todo a sua obra a questão da excepcionalidade da política sem nunca oferecer uma resposta para o paradoxo por ele proposto: o fato de que a igualdade, condição para o exercício da política, é estranho a esta. Rancière observa que a democracia consensual, aquela que se localiza após o conflito, seria oposta a democracia real, significando a anulação da política. Mas ele mesmo admite que a política é sempre rara, local e ocasional. Assim, parece que o autor ainda não consegue escapar desse movimento circular da política (que aqui também pode ser entendida como o próprio poder constituinte) que aparece como forma de romper a ordem vigente, mas acaba por estabelecer uma nova ordem e é anulada até que haja um novo desafio a essa ordem.

É nesse ponto que se mostra fundamental a tese apresentada por Negri em "O Poder Constituinte”. A sua grande preocupação 'r a de pensar um poder constituinte que não seja limitado pelas instituições do constitucionalismo. 
Assim, o autor ataca a racionalidade da modernidade como forma de viabilizar o exercício de um poder constituinte verdadeiramente ilimitado. Para ele, é fundamental que se rompam com conceitos intrinsecamente ligados ao Ocidente: a tradição judaico-cristã, que concebe a criação como um momento unitário; a perspectiva jusnaturalista; e o transcendentalismo. Segundo o autor, apenas rompendo com esse pensamento, é possível pensar em uma poder constituinte ilimitado, que veja o limite apenas como medida de sua expansão.

É nesse sentido que Negri cunha o seu conceito de antipoder. O antipoder possui três etapas: a resistência, a insurreição e o poder constituinte. Mas o importante de se ter em mente quando se pensa no antipoder é que ele não pode atuar como substituto ao poder anterior. O que o autor propõe é que a resistência e a insurreição sirvam para desestabilizar e derrubar as forças no poder, mas que o poder constituinte seja entendido como potência, sempre dinâmico e expansivo, uma imaginação constituinte que não se conforme a uma forma pré estabelecida.

E é nesse ponto que se encontra a grande diferença entre os dois autores aqui destacados. Enquanto o primeiro entende o poder constituinte por uma perspectiva limitada, seja temporalmente (a política é excepcional, é ocasional), seja geograficamente (a política é sempre local), o segundo se esforça por pensar um poder constituinte como uma força transformadora ilimitada, que atue em âmbito global.

Ambos autores são claros em afirmar que no momento atual de nossa sociedade não estamos vivenciando uma democracia real. Nenhum dos dois também é capaz de apresentar exemplos concretos em que se possa observar alguma centelha do surgimento dessa democracia. No panorama atual, parece que toda força constitutiva se encontra aprisionada nas amarras do poder constituído. Mas Negri conclui sua obra em um tom otimista, ainda que moderado. Para ele, se é difícil pensar em uma história de liberdade, podemos ao menos pensar em um futuro de liberação: 
"Uma história de liberdade, a que nos espera? Seria tolice afirma-lo, diante das horrendas mutilações que o poder constituído continua a infligir ao corpo ontológico da liberdade dos homens, diante da perpétua negação que se opõe à série inquebrantável liberdade-igualdade-potência da multidão. Mas uma história de liberação, esta sim nos espera: desutopia em ato, incontrolável, tão dolorosa quanto construtiva. A constituição da potência é a própria saga da libertação da multitudo. Que o poder constituinte não pode senão aparecer desta forma e com esta força, é indiscutível; que ele não pode senão se afirmar como hegemonia no mundo da vida sempre renovado, é necessário. Cabe a nós acelerar essa potência e, no amor do tempo, interpretar a sua necessidade."

${ }^{90}$ Ibid., p. 461 


\section{BIBLIOGRAFIA}

CANGUILHEM. Georges. O Normal e o Patológico; tradução de Maria

Thereza Redig de Carvalhos Barrocas. Revisão Técnica de Jorge Alberto Costa e Silva. ed. 3, rev. e aumentada . Rio de Janeiro: Editora Forense Universitária, 1990

CHAUÍ, Marilena. Política em Espinosa. São Paulo: Companhia das Letras, 2003

DA SILVA, José Afonso. Curso de Direito Constitucional Positivo. 32. ed. rev. e atual. São Paulo. Malheiros Editores. 2009

DE GUIMARAENS, Francisco. O Poder Constituinte na perspectiva de Antonio Negri - Um conceito muito além da modernidade hegemônica. Dissertação (Mestrado em Direito). Rio de Janeiro: PUC, Departamento de Direito, 2002.

HARDT, Michael e NEGRI, Antonio. Multidão - Guerra e democracia na era do Império; traduzido por Clóvis Marques. Rio de Janeiro: Record. 2005

MENDES, Gilmar Ferreira et al.. Curso de Direito Constitucional. 4. ed. rev. e atual. São Paulo. Saraiva. 2009

MIRANDA, Jorge. Teoria do Estado e da Constituição. Rio de Janeiro: Forense, 2003

MORAES, Alexandre de. Direito Constitucional - 20 ed. - São Paulo: Atlas, 2006.

NEGRI, Antonio. O Poder Constituinte - ensaio sobre as alternativas da modernidade; tradução de Adriano Pilatti - Rio de Janeiro: Ed. 1, DP\&A, 2002

Cinco Lições sobre Império. Traduzido por Alba $\begin{array}{llll}\text { Olmi. Rio de Janeio: } & \text { DP\&A, }\end{array}$ 
RANCIÈRE, Jacques. O Desentendimento - política e filosofia; tradução de Ângela Leite Lopes - São Paulo: Ed. 1. Editora 34, 1996 O dissenso IN A Crise da Razão. Organizador Adauto Novaes - São Paulo: Companhia das Letras: Brasília, DF. Ministério da Cultura. Rio de Janeiro. Fundação Nacional de Arte, 1999 - O Mestre Ignorante - Cinco lições sobre a emancipação intelectual. Traduzido por Lilian do Valle. Ed. 2. Belo Horizonte: Editora Autêntica, 2005

SIEYÈS, Emmanuel Joseph. A constituinte burguesa: Qu'est-ce que letiersétat? - $4^{a}$ ed. Organização e introdução de Aurélio Wander Bastos. Tradução. por Norma Azevedo. Rio de Janeiro: Lumen Juris, 2001

SPINOZA, Benedictus de. Ética; tradução e notas de Tomaz Tadeu - 2 . ed., Belo Horizonte: Autêntica Editora, 2008. Carta $\mathrm{n}^{\circ} 50$, de 2 de junho de 1674 